Harris, K. \& Bradley, D. E. (1960). J. gen. Microbiol. 22, 750-777

\title{
A Taxonomic Study of Mallomonas
}

\author{
BY KATHARINE HARRIS \\ Department of Botany, University of Reading \\ AND D. E. BRADLEY \\ Research Laboratory, Associated Electrical Industries, Aldermaston Court, \\ Aldermaston, Berkshire
}

\begin{abstract}
SUMMARY: Species of Mallomonas known with the electron microscope are arranged in a new scheme of classification, extending that previously proposed. A number of new species are described and some known ones examined for the first time with the electron microscope. The development and internal structure of the scales of certain species is described. The proposed scheme of classification was developed as a result of the high resolving power of the electron microscope which enabled us to interpret features which can be faintly seen with the optical microscope. The scheme can, we believe, be used where the optical microscope alone is available. The feature which we have selected as the basis of classification differ from those selected by workers with the optical microscope only.
\end{abstract}

\section{METHODS}

The methods of collection and preparation for examination with optical and electron microscopes have already been described by Harris (1953) and Harris \& Bradley (1957), and will not be repeated here.

Electron microscopy. The electron microscope can be used in two ways when studying Mallomonas. Electron micrographs of the scales themselves may be taken directly or replicas may be prepared of either the scales or the whole organism. Direct examination of the scales provides a two-dimensional picture only, the contrast being produced by the variation in thickness of the silica which constitutes the scale. Thus a deep pit and an internal cavity will be equally represented by a pale area in the electron micrograph. Complete organisms cannot be studied directly since they are opaque to electrons.

The shadowed replica is in fact a cast and an electron micrograph of this shows surface configuration and nothing else. Replicas can show both inner and outer surfaces of different scales. Replicas of complete organisms show the arrangement of the unbroken cell armour.

Explanation of terms. Most of our terms have been used in previous publications (Harris, 1953; Harris \& Bradley, 1957; Asmund, 1959). Those concerning the scales are shown in Figs. 1 and 2, while the position of a scale in the cell armour is described by the words 'anterior' and 'posterior' for the two ends and 'body' scale for any other position on the cell. In addition, we call the end of the scale which overlaps its neighbour, the 'distal end'; in bristle bearing scales this is where the bristle is attached. The end of the scale overlapped by its neighbour is called the proximal end. These new terms are also shown in Figs. 1 and 2. 
Juvenile scales. When observing samples of a rich community of some species, over a period of 1-3 weeks, we noticed that in the earlier samples many individuals lacked certain characters which we associated with the typical mature cell. The rear scales might, for example, lack dome and bristle, lack certain marks, or be unusually small. The number of such abnormal cells in the sample became fewer as time advanced and the majority of the cells approached encystment (Harris, 1953). We think that these individuals represent a developmental stage and we call them juvenile cells. When examining some of our species with the electron microscope we noticed that while in some cells the rear scales were formed as described in our diagnosis, in other cells the rear scales were smaller, simpler and lacked expected characters. For example Mallomonas intermedia var. gesticulans in Fig. 1 has rear scales in every way like the body scales, while the scales from another cell (Fig. 8) are without dome and are abnormally small. We think that these scales were part of a juvenile individual, as mentioned above, and we call them 'juvenile' scales. Though small and simple, they are fully thickened scales.

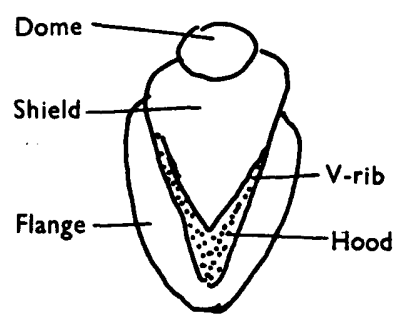

Fig. 1

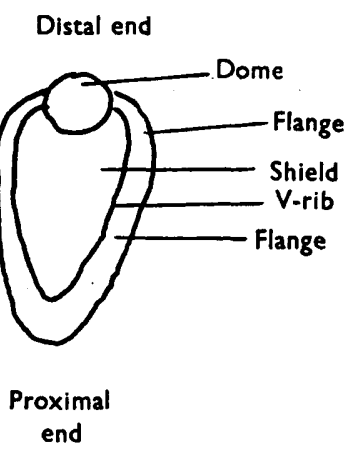

Fig. 2

Figs. 1 and 2. Diagrams of tripartite scales.

We occasionally found scales which, though normal in length and breadth, were unusually thin, and lacked some, or all, of the sculpturing on the outer side. These were quite distinct from the juvenile scales and we call them 'immature' scales. We think that they were in the process of being formed when the cell was killed; they may occur, singly or in groups, at any point in the cell armour. We know that scales are shed by the cell at certain times and suggest that the immature scales replaced ones recently shed.

\section{PROPOSED CLASSIFICATION OF MALLOMONAS}

The species of Mallomonas have been grouped in different ways. Conrad (1933) used the shape of the cell, the presence or absence and position of the bristles, and the structure of the scales; Bourrelly (1957) modified Conrad's grouping and limited himself to the use of optical microscope. Harris \& Bradley (1957) suggested a different grouping for a few species, based on the structure of their scales as seen in the electron microscope. We now extend 
this scheme to a much larger number of species seen in this way. The electron microscopic characters are not, in fact, mentioned in the conspectus, but they have played an essential part in convincing us that certain features, visible under the optical microscope, are of real and fundamental importance.

\section{Series I. Tripartiae}

Some, or all scales bear bristles.

Scales concave and thin.

Bristle bearing scales have well-marked dome, shield and flange.

Scale outlines, when visible on the surface of the living cell, do not appear as rhomboids.

\section{A. The acaroides group}

Scales large and broad. Dome large and prominent.

Outline of living cell irregular.

Scales, if visible on the surface of living cell, appear as ovals.

\section{B. The striata group}

Scales small, narrow. Dome small, prominent.

Outline of living cell nearly regular, with peg-like projections.

Scales from a brick-like pattern on the surface of living cell.

C. The papillosa group

Scales small. Dome large but not prominent.

Cell outline nearly smooth.

Scales not visible on surface of living cell.

\section{Series II. Planae}

Some or all scales bear bristles.

Scales flat and thin with no dome.

Scale outlines not easily visible on surface of living cell.

\section{Series III. Quadratae}

Anterior scales sometimes bear bristles, other scales without bristles.

Scales convex and thick.

Scales have no dome or flange.

Scale outlines visible as rhomboids on surface of living cell.

\section{Series IV. Torquatae}

Anterior scales point forwards and form collar round flagellum.

Anterior scales usually bear bristles, other scales without bristles.

Scales concave and thin.

Anterior scales have dome, body scales without dome but may, or may not, have narrow flange.

Scale outlines usually apparent on living cell as rhomboids. 


\section{ISOLATED SPECIES}

Mallomonas insignis Penard.

Anterior scales have conspicuous spines.

No scales bear bristles.

Scales strongly concave and thick.

Scale outlines visible as pattern of rhomboids or hexagons, on surface of living cell.

Cell much elongated and rear attenuated.

Mallomonas akrokomos Pascher

Bristles present on anterior scales only.

Scales nearly flat.

Bristle bearing scales have a dome.

Scales not visible on surface of living cell.

Cell strongly elongated, tapering to a point at rear.

Mallomonas ouradion Harris \& Bradley

All scales bear bristles.

Several bristles present on a single scale.

Scales thin and concave.

Scales have no dome but have well-marked flange.

Scales not visible on surface of living cell.

\section{SPECIES WHICH HAVE BEEN EXAMINED WITH THE ELECTRON}

\section{Tripartitae}

\section{MICROSCOPE}

The acaroides groups

Mallomonas ascaroides Perty var. striatula Asmund (1959)

Asmund

Mallomonas acaroides Perty var. crassisquama Asmund (1959); cf. TakaAsmund

Mallomonas acaroides Perty var. galeata var. nov.

M. intermedia Kisselew var. soleatus Asmund

hashi (1959)

This paper

Asmund (1959); syn.

$M$. soleatus Harris \&

Bradley (1957)

M. intermedia Kisselew var. gesticulans

This paper

M. leboimei Bourrelly

Harris \& Bradley (1957);

M. tonsurata Teiling

M. tonsurata Teiling var. alpina Fott

Asmund (1959)

Asmund (1959)

Fott (1955); (we believe this to be $M$. acaroides juvenile form)

M. tonsurata Teiling var. alpina Asmund Asmund (1959), (syn. M. monograptus juvenile form.) This paper. 
Tripartitae (cont.)

M. tonsurata Teiling

$M$. monograptus sp.nov.

$M$. areolata Nygaard

M. elongata Reverdin

$M$. pediculus Teiling var. echinospora

Nygaard

M. lelymene sp.nov.

M. palludosa Fott

The striata group

Mallomonas striata Asmund

Mallomonas striata Asmund var. serrata var.nov.

M. flora sp.nov.

M. cratis sp.nov.

striata group

The papillosa group

Mallomonas papillosa Harris \& Bradley

Planae

Mallomonas caudata Ivanoff

M. fastigiata Zacharias syn. M. caudata Ivanoff

M. regina Teiling

M. heterospina Lund

M. multiunca Asmund

M. teilingii Conrad

M. oviformis Nygaard

M. hamata Asmund

\section{Quadratae}

Mallomonas allorge (Deflandre) Conrad M. lychenensis Conrad

M. adamas sp.nov.
Cf. Takahashi (1959)

This paper

Asmund (1959)

Asmund (1959)

Asmund (1959)

This paper

Fott (1959)

Asmund (1959)

This paper

This paper

This paper

Cf. Takahashi (1959)

Harris \& Bradley (1957); this paper; cf. Takahashi (1959)

Asmund (1955)

Fott (1959)

Harris \& Bradley (1957);

cf. Takahashi (1959)

Asmund (1956); Harris

\& Bradley (1957); cf.

Takahashi (1959)

Asmund (1956); Harris

\& Bradley (1957); this

paper

Asmund (1956)

Asmund (1959); this

paper

Asmund (1959)

This paper

Harris \& Bradley (1957)

This paper 


\section{Torquatae}

Mallomonas doigonii Bourrelly

M. mangofera sp.nov.

M. phasma sp.nov.

M. pumilio Harris \& Bradley

M. pumilio var. silvicola var. nov.

M. coronifera Matv.

ISOLATED SPECIES

Mallomonas insignis Penard

M. akrokomos Pascher

M. ouradion Harris \& Bradley
Harris \& Bradley (1957);

(wrongly named

M. coronata)

This paper; cf. Takahashi (1959)

This paper

Harris \& Bradley (1957)

This paper

Fott (1959)

Note. Takahashi (1959) published a large number of unnamed electron micrographs of Mallomonas, some of which closely resemble named species and are therefore referred to above.

\section{SERIES I. TRIPARTITAE}

The acaroides group

\section{Mallomonas acaroides Perty 1851}

This species was emended by Pascher (1913) and Krieger (1932). Conrad (1933) cites the literature up to 1933. Woloszynska (1939), and Asmund (1959) have described varieties.

Mallomonas acaroides var. galeata var. nov. (Figs. 9-12, and Pl. 1, figs. 2-5, 7)

Diagnosis. A typo differt in scuto sine punctis minutis et in V-costa sine punctis majoribus et in setis omnibus cum apicibus galeatis. (Optical microscope.)

English diagnosis. Differs from the type in having scales without fine dots on the shield and the V-rib without larger dots and in having all its bristles with helmet-shaped tips. (Optical microscope.)

Dimensions. Cell 13-33 $\mu \times 10-17 \mu$, scales 4-7 $\mu \times 3-4 \mu$, bristles (mature cell) $20-35 \mu$, cyst $20 \mu$ diameter.

Occurrence. It was found in several of the pools of a small gravel pit at Woodley, Berkshire, Nat. Grid 477/173. It was abundant from September to December in 1950 and 1951. Cysts occurred in December in a bottle which had been kept for $24 \mathrm{hr}$. This gravel pit is now being vigorously worked and the organism has not been found since 1951.

Comparison of the varieties of $\boldsymbol{M}$. acaroides examined with the electron microscope shown in Table 1.

A shield showing strong reticulation with the electron microscope will appear punctate with the optical microscope and a flange showing strongly 

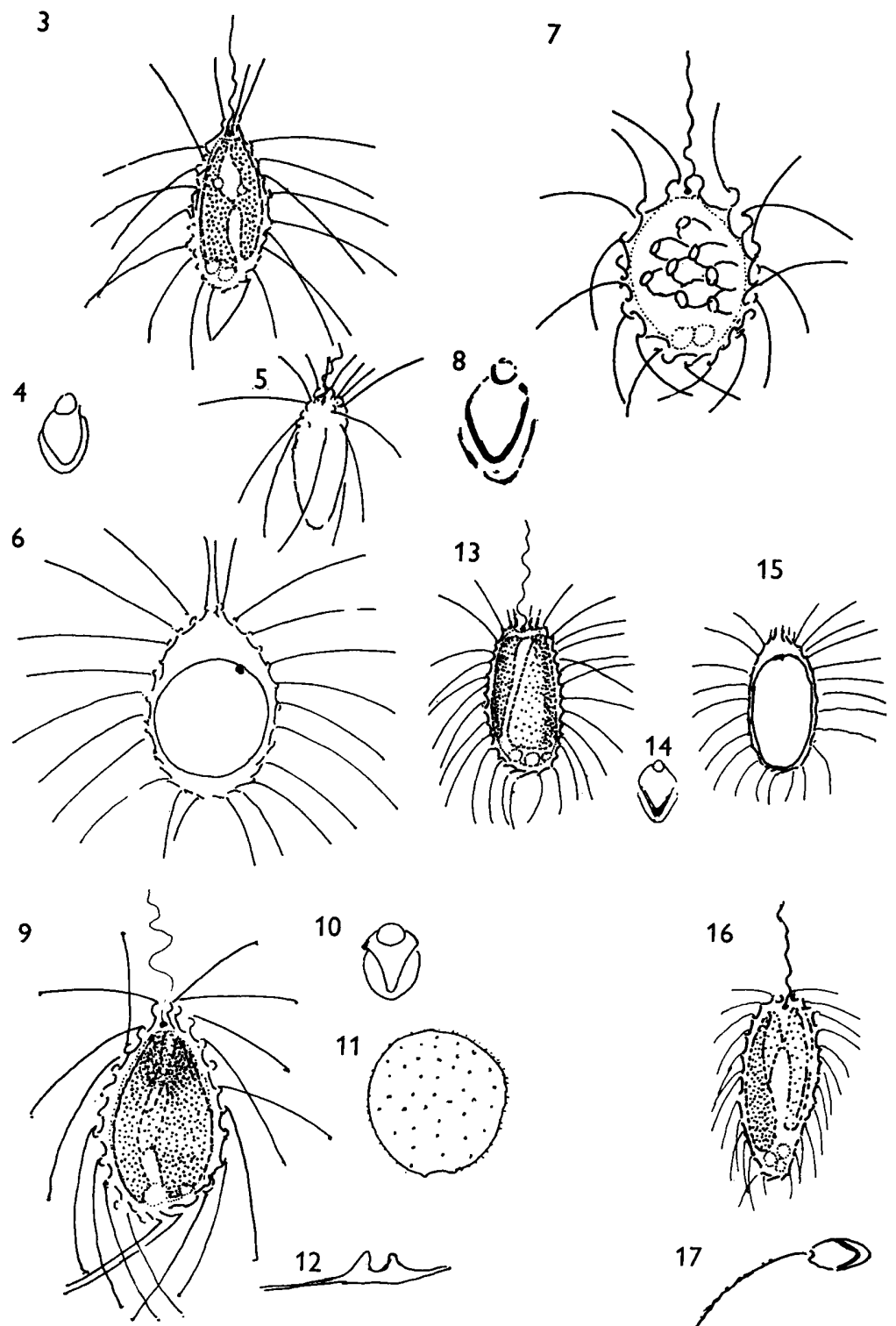

Figs. 3-17. 3. Mallomonas monograptus, mature cell showing bilobed chromatophore and contractile vacuoles and bristles pointing in various directions, $\times 1000$. 4. M. monograptus, body scale, $\times 2000$. 5. M. tonsurata, mature cell, $\times 1000$. 6. M. monograptus, with cyst, $\times 1000$. $7 . M$. lelymene, with some scales as seen on surface of cell and bristles pointing in various directions, $\times 1000$. 8. M. lelymene, body scale $\times 2000.9 . M$. acaroides, mature cell showing bilobed chromatophore, nucleus, and bristles pointing in various directions, $\times 1000$. 10. M. acaroides, body scale, $\times 2000.11$. M. acaroides, cyst, $\times 1000$. 12. M. acaroides, bristle tip, $\times 2000$. 13. M. striata var. serrata, mature cell showing chromatophore lobes and contractile vacuoles, $\times 1000$. 14. M. striata var. serrata, body scale, $\times 2000$. 15. M. striata var. serrata, with cyst, $\times 1000$. 16. M. flora, mature cell showing bilobed chromatophore, and contractile vacuoles, $\times 1000.17 . M$. flora, body scale with bristle, $\times 2000$. 
Table 1

$\begin{array}{clcl} & \text { Var. striatula } & \text { Var. crassisquama } & \text { Var. galeata } \\ \text { Bristles } & \begin{array}{c}\text { Two sorts } \\ \text { with and without } \\ \text { helmet tip }\end{array} & \begin{array}{c}\text { Two sorts } \\ \text { with and without } \\ \text { helmet tip }\end{array} & \begin{array}{c}\text { One sort } \\ \text { all with helmet } \\ \text { tip }\end{array} \\ \begin{array}{c}\text { Scales at } \\ \times 10,000\end{array} & \begin{array}{l}\text { Shield mostly } \\ \text { smooth }\end{array} & \begin{array}{c}\text { Shield strongly } \\ \text { reticulate }\end{array} & \begin{array}{c}\text { Shield mostly } \\ \text { smooth }\end{array} \\ & \begin{array}{c}\text { Flange lightly } \\ \text { ribbed }\end{array} & \begin{array}{c}\text { Flange strongly } \\ \text { ribbed }\end{array} & \begin{array}{c}\text { Flange lightly } \\ \text { ribbed }\end{array} \\ \text { Dome at } & \text { Some with slight } & \text { Some with strongly } & \text { Some with slight } \\ \times 10,000 & \text { crest } & \text { marked crest } & \text { crest } \\ \text { Entire cell } & \text { Does not have } & \text { Has rear scales } & \text { Does not have } \\ & \text { rear scales with } & \text { with spines } & \text { rear scales with } \\ & \text { spines } & & \text { spines }\end{array}$

marked ribs with the electron microscope will show clear, but slight, striations with the optical microscope. Slight ribs seen with the electron microscope may, or may not, be visible with the optical microscope.

We notice that the electron micrograph (Pl. 5) published by Fott in 1955, which he determined as $M$. tonsurata Teiling var. alpine (Pasch, et. Rut) Kreig. is very much more like our PI. 1, fig. 7, of $M$. acaroides var. galeata than it is like $M$. tonsurata Teiling (Fig. 3, Asmund, 1959). The bristles figured by Fott lack the typical expanded tip of $M$. acaroides and its varieties, but this would be accounted for if the cell used were in a juvenile stage. Several of the scales shown in his figure at $\times 2500$ lack domes, which suggests the juvenile condition. In our observation the bristles of juvenile cells of $\boldsymbol{M}$. acaroides var. galeata normally lack an expanded tip. We suggest that a juvenile cell of $\boldsymbol{M}$. acaroides has been mistakenly determined as $\boldsymbol{M}$. tonsurata var. alpina.

Mallomonas intermedia Kisselew (1931). (Pl. 1, figs, 1, 6, 8, 9, 10)

History. M. intermedia was described by Kisselew in 1931, in 1942 Lund modified the description and added new details, and in 1953 Harris described $M$. intermedia var. gesticulans. All these descriptions were made with the optical microscope only. Harris \& Bradley (1957) described $M$. soleatus with both optical and electron microscopes. At this time no material of $M$. intermedia var. gesticulans was available for comparison with the electron microscope but as soon as this comparison was made it became clear that the differences between $M$. soleatus and $M$. var. gesticulans were very slight. In 1959, with our approval, Asmund published a description of $M$. intermedia var. soleatus from Danish material which we believe to be identical with our material and the name $M$. soleatus is superseded.

It is not possible to compare the varieties of $M$. intermedia with the type as interpreted by Kisselew or Lund since these are not described in sufficient detail and no material is available for electron microscopical examination.

Comparison of var. gesticulans and var. soleatus. In var. gesticulans the outline of the living cell shows few domes except immediately surrounding 
the flagellum. The bristles look smooth when seen in the optical microscope and are shallowingly serrate, often only near the free end, or smooth, with the electron microscope. The cysts are spherical with widely spaced inconspicuous pits visible with the optical microscope. The dimensions of the cell are slightly larger than those of var. soleatus, $15-40 \mu \times 12-16 \mu$.

In the outline of var. soleatus domes are conspicuous all round the cell, not only at the anterior. The bristles look rough, with the optical microscope, and coarsely serrate with the electron microscope. The cysts appear smooth with the optical microscope and are nearly spherical, often slightly pointed at the pore. The cell of var. soleatus is commonly smaller than that of var. gesticulans and reaches only $30 \times 16 \mu$ instead of $40 \times 16 \mu$.

It is clear from the foregoing comparison that the differences between $\boldsymbol{M}$. var. gesticulans and $\boldsymbol{M}$. var. soleatus are more conspicuous in the light microscope than in electron micrographs, where the only difference appears to be the degree of serration of the bristles. The most striking difference in the appearance of the living cell is due to the presence of rings, representing domes, in the outline of the living cell of var. soleatus, and this is not explained by anything we can see in the electron micrographs. Possibly a stereoscopic electron micrograph might be helpful. It is unlikely to be merely a developmental variation since var. gesticulans has been examined during all its recognizable life cycle (Harris, 1953) and no cells with prominent rings have been found.

$M$. intermedia has a number of local forms which have been found repeatedly in the same pond and differ in some small detail from the varieties described. An interesting form shows bristles with an elongated tip (Pl. 1, fig. 6). The scales are normal and its optical appearance is very close to var. soleatus. Another form, which differs in the optical microscope but has not yet been investigated with the electron microscope, is found in ponds on acid peat or in woods. Here even more small rings, representing domes, are seen in the outline of the living cell than in var. soleatus

Occurrence. $M$. var. gesticulans, $M$. var. soleatus, and the form with the elongated bristles all occur in similar localities in ponds by roadside, or in park land, bordered by trees. They have not been found in ponds heavily contaminated with dung. The species occurs for a short period between January and the following June and so far as we know, once the cysts have been formed it does not recur until the following year.

Mallomonas lelymene, sp.nov. (Figs. 7, 8; P1. 2, figs. 11-14)

Diagnosis. Cellula rotundata-ovoides, setis fortibus contecta. Chromatoporum colore viridi fusco. Squamae magnae et crassae, in cellula viva facile conspicuus, in cupolam, scutum et marginem divisae. Cupola prominens foveolata, laciniis lateralibus protenus in scutum partim extendens, scutum iugis prope viginti transversis signatum inter singular ordine unico fovearum signatum. V-costa crassa, mitellam habente, limbo reflexo, superficies V-costa laevis, sed intus trabibus radiatis instructa. Margo lata labio imminente, limbo reflexo, superficies levis sed intus trabibus radiata instructa. Squama 


\section{A taxonomic study of Mallomonas}

infra levis. Seta arcuata pede angusto, truncus fortis, dentibus parvis obtusis armatus, apex simplex. Cystum ignotum.

Dimensiones. Cellula 19-27 $\mu \times 13-17 \mu$, squamae 7-10 $\mu \times 4-5 \mu$, setae 10$13 \mu$.

English diagnosis. Cell round ovoid, covered with stout bristles, Chromatophore brownish green. Scales large, thick, easily visible in living cell, composed of dome, shield and flange. Dome prominent, pitted, with lateral extensions running part way along shield. Shield marked with about twenty transverse ridges showing a single row of cavities between each pair. V-rib thickened and hooded with turned back flap, surface of V-rib smooth but interior showing radial struts. Flange broad with overlapping rim which has turned back flap, surface smooth but interior has radial struts. Under side of scale smooth. Bristles curved, foot narrow, shaft thick with small obtuse teeth, apex simple. Cyst unknown.

The name, lelymene, meaning ' with dishevelled hair', refers to the somewhat untidy appearance of the organism when the bristles, as often happens, point in different directions. Sometimes, however, when the organism is swimming, the bristles may all be directed backwards, slightly spirally, and its appearance is far from untidy.

Occurrence. $M$. lelymene was found in small flooded pools on Hartford Flats, a dry peaty plateau, Nat. Grid $483 / 160, \mathrm{pH}$ readings 4.9 and $5 \cdot 3$. It has been recorded from November to February, sometimes occurring under ice, and also in June. It probably occurs, regardless of temperature, whenever the water lies long enough for it to develop but does not persist for long.

$M$. lelymene is recognizable when living by its conspicuous scales and short stout curved bristles. The scales differ from all others at present known, by the lateral extensions at the sides of the dome and the very regular rows of cavities across the shield. The V-rib and margin of the flange are thicker and broader than in other species.

Mallomonas monograptus sp.nov. "Juvenile form $M$. tonsurata var. alpina" Asmund (1959) non Teiling. (Figs. 3, 4, 6, Pl. 2, figs. 15-17.)

Diagnosis. Cella ovoides, post rotundata, ante obtusa, setis longis arcuatis contecta. Chromatophorum colore pallidulo. Squamae tenues in cupolam, scutum et marginem divisae. Cupola satis magna, tertia tenus parte longitudinis squamae, saepe in apice jugis brevibus, paucis per longitude signata. Scutum saepe inequale, aequaliter fovis signatum, V-costa finitum. Margo foveis signata, labro crasso finita. Cupola infra levis, scutum et margo punctata. Seta arcuata, alte sulcata, attenuata in finem, dentes acutos ferens. Cystum globosum, leve, poro oblique anteriore.

Dimensiones. 14-38 $\mu \times 8-15 \mu$, squamae 4-7 $\mu \times 3-4 \mu$, setae 9-24 $\mu$ cystum 16-17 $\mu$.

English diagnosis. Cell ovoid, rounded at rear, bluntly pointed at anterior, covered with long curved bristles. Chromatophore rather pale. Scales delicate, divided into dome, shield and flange. Dome relatively large up to onethird scale length, frequently marked on top with a few ridges. Shield often 
asymmetrical, with scattered perforations bounded by V-rib. Under side of dome smooth, under side of shield and flange punctate. Bristles curved, bearing sharp teeth, strongly grooved, tapering. Cyst spherical, smooth with obliquely anterior pore.

The name monograptus refers to the bristles which recall the fossil monograptus.

Additional characters. The bristles at the anterior end are always shorter than those on the body scales and are seen in the electron microscope to be stouter. The rear scales also have shorter bristles than those of the body scales.

Occurrence. M. monograptus has been found in a variety of localities: a gravel pit, at Woodley type locality, Nat. Grid 447/173, a clay pit, and several small lakes. They have little in common except the absence of dung contamination. It has been found at most times of year and cysts have been found from January to May.

In one locality, at Billingsbeare, a smaller form occurred. The few cysts found measured $11 \mu$ diameter.

We have found $\boldsymbol{M}$. monograptus to be easily recognizable, in its mature form, with the optical microscope, by its size, delicate appearance, pale colour, and absence of any thickened or refractive bristle tip. In its juvenile form, however, it is not easy to distinguish from $M$. tonsurata Teiling. The scales of $M$. tonsurata have a great deal in common both in direct electron micrographs and in replicas. The bristle bearing scales of both species have large domes which sometimes have an extension forwards (compare the upper and lower domed scales in Pl. 2, fig. 16). The shield and flange of both species in bristle bearing and bristle-less scales have perforations which may be scattered or arranged in rather irregular rows. These perforations are small on both the inner and outer surfaces, as shown in the replicas, but wider in the interior of the scale, as shown in the direct electron micrographs. Both species have an area in the angle of the V-rib where the perforations are smaller and closer than over the rest of the scale.

We give a summary of the differences between $M$. monograptus and $M$. tonsurata Teiling. We found $M$. tonsurata near Reading, both in early stages and with its cyst, and this agreed closely with the Teilings figures.

\section{Mallomonas tonsurata Teiling (Fig. 5)}

1. The scales covering the rear third or more of the cell are always without domes and bristles even at encystment.

2. The cyst is papillose and has a small distinct collar round the pore.

3. The bristles are of two kinds, five or six anterior bristles being serrate and the rest smooth, with a forked tip.

4. Well-developed scales have a sharply defined thin area, or 'window' in the angle of the V-rib.

5. The dome is smooth and without ridges.

Mallomonas monograptus sp.nov.

1. Domed scales bearing bristles are present at the rear end of mature and encysted cells. 
2. The cyst is smooth and has no collar or rim round the pore.

3. The bristles are all serrate.

4. There is a group of particularly small perforations in the angle of the V-rib but no thin area or 'window'.

5. The dome is marked by one to five longitudinal or oblique ridges.

Mallomonas tonsurata Teiling var. alpina (Pascher \& Ruttner) Krieger

This species resembles the type in lacking bristles at the rear end but differs from it in that all the bristles are serrate instead of some serrate and the rest forked. The cyst is identical with that of the type. We have never seen this variety and cannot give any direct comparison between it and $M$. monograptus.

\section{The striate group}

None of the species of this group were described before the advent of the electron microscope. The group is easily recognizable by the close, rather regular, peg-like projections of the cell outline, and also by the brick-like pattern which the scales make on the surface of the living cell. The group appears to be very common, but the scales are so small and the differences between species have been so lacking in precision, that it was impossible to describe them with the optical microscope. The electromicrographs of this group, except $\mathrm{Pl}$. 3, figs. 27 and 28 , are reproduced at a larger magnification than most of the other species.

\section{Mallomonas striata Asmund}

This species was described by Asmund (1959) and is a common cold-water species in Denmark. It has not yet been found in Britain, but a closely related variety has been found.

Mallomonas striata var. serrata var.nov. (Figs. 13-15; Pl. 3, figs. 19, 20; Pl. 4, fig. 29)

Diagnosis. A typo differt in cellulam minorem et in setis subtiliter serratis. Cystum ovale, leve, poro antico sine crassa.

Dimensiones. Cellula $12-19 \mu \times 9-10 \mu$, setae 8-12 $\mu$, squamae 3-41 $\mu \times 1 \frac{1}{2}$ $3 \mu$, cystum $16 \times 9 \frac{1}{2} \mu$.

English diagnosis. Differs from type in having smaller cell and finely serrate bristles. Cyst oval, smooth, with anterior pore without rim.

Occurrence. Var. serrata was found once, in large numbers, in a flooded field near Eversly, Nat. Grid 477/163.

Two other features are characteristic of var. serrata and have not been observed in the type. The cell has about five triangular non-bristle-bearing scales round the flagellum. These scales are drawn out into long fine spines which look like very short bristles in the optical microscope. They are visible but very inconspicuous in the optical microscope and we have therefore not mentioned them in our diagnosis. Var. serrata has bristles all round the cell while the type is described as having no bristles at the rear. It may be that individuals of the type $M$. striata were slightly juvenile, in which case no bristles would be expected at the rear. We have therefore omitted this difference from our diagnosis. 
Comparison. $M$. var. serrata may be distinguished with the optical microscope from all other species of the striata group described here by being smaller in size and having finely pointed anterior scales, looking like minute bristles, round the flagellum. The scales of both $M$. striata and var. serrata may be distinguished, in the electron micrographs, by the lack of concentric $U$ forms on the dome and by the angular rather than rounded corners of the shield.

Pl. 4, fig. 29, shows a replica of a complete unbroken mature cell. The anterior scales with drawn-out points may be seen. No isolated scales of this type have been obtained. The length of the drawn-out tip varies in the three examples we have seen, sometimes being equal to the length of the scale and sometimes shorter.

Mallomonas flora sp. nov. (Figs. 16, 17, Pl. 3, figs. 21, 22, 25 and 28)

Diagnosis. Cellula ovoides, setis arcuatis in denso ordine contecta. Squamae in cupolam, scutum et marginem divisae, angustae, concavae. Cupola parva sed prominens, costis prope sex concentricis signata. Scutum duodecem costis transversis et $V$-costa finitum parum impendente et latiore costae prope mitram interuptae, ornamento parvo floriformi. Margo angusta, labro crasso finita prope sedecim costis radiatis signata. Squama multis foveis signata, foveis sparsis non in ordinibus positi. Squama infra levis. Seta arcuata, pede attenuato, truncus profunde sulcatus dentibus brevibus nonnullis procul armatus. Cystum ignotum.

Dimensiones. Cellula 17-29 $\mu \times 8-13 \mu$, squama 4-6 $\mu \times 3-4 \mu$, seta $7-13 \mu$.

English diagnosis. Cell ovoid, covered all over with closely set curved bristles. Scales consist in dome, shield and flange, narrow, concave. Dome small but prominent, marked by about six concentric ribs. Shield marked by about twelve transverse curved ribs and bounded by a V-rib which is hooded, and has four small teeth. Ribs interrupted near hood by small flower-like pattern. Flange narrow with thickened rim and marked by about sixteen radial ribs. Scale marked by numerous scattered cavities. Inner surface of scale smooth. Bristle curved, foot tapering, shaft deeply grooved with few small teeth at distal end. Cyst not known.

Found in somewhat acid ponds on peat or near Sphagnum. Recorded in February and April from a few localities only. Type found at Westwood, Sunningdale, Nat. Grid 494/167.

The name 'flora' = 'flower' refers to the flower-like patterns on the shield. Features distingishing $M$. flora:

1. The scale is broader in relation to its length than other species described and this makes the outline of the living cell more irregular than that of the other species.

2. The shield has a flower-like pattern in the angle of the V-rib.

Mallomonas cratis (Figs. 18-20; Pl. 3, figs. 18, 23, 24, 26 and 27)

Diagnosis. Cellula ovoides, setis arcuatis densis contecta. Nucleus magnus, conspicuus in anteriore parte cellulas positus. Squamae angustae concavae, 
in cupolam, scutum et marginem divisae. Cupola parva sed prominens, costis quatuor vel quinque $U$ formis concentricis signata. Scutum prope duodeviginti costis subarcuatis transversis signatum et labro crasso finitum latiore impendente oppositam, dentes quattuor vel quinque in mitra praesens. Margo angusta labro crasso finita, pars interior viginti costis radiatis obscuris instructa. Squama tota multis foveis minutis signata inter costa sparsis. Setae serratae. Cystum ovatum vel subrotundum superficies levis vel scortea, porus anterior in regionem setis planum, aliquando ora crasso.

Dimensiones. Cellula $17-33 \mu \times 12-20 \mu$, squama $5 \frac{1}{2}-7 \mu \times 2 \cdot 5-3 \mu$, seta 6$15 \mu$, cystum $20 \times 22 \mu$.

English diagnosis. Cell ovoid, covered all over with closely set curved bristles. Large conspicuous nucleus occupying anterior part of cell. Scales narrow concave, consisting of dome, shield and flange. Dome small, marked by four or five concentric U-shaped ribs. Shield marked by about eighteen transverse slightly curved ribs and V-rib which is hooded and has four or five small teeth. Flange narrow with thickened rim, inner part crossed by twenty or more obscure radial struts. Whole scale marked by minute scattered cavities. Bristle finely serrate. Cyst ovoid to almost spherical, smooth or slightly shagreened, pore anterior in flattened area with, or without slight rim.

Occurrence. Found in brackish pools behind sand or shingle near the sea. Has been found in several places near Lee-on-Solent on south coast of Hampshire and near Aust, Bristol. Type from Lee-on-Solent.

The name 'cratis' = 'basket' was suggested by the superficial marking of the scales in the replica of the cell.

Distinguishing features of $M$. cratis:

1. Its unusually large and conspicuous nucleus.

2. Its scale is longer in relation to its breadth than those of the other species described.

3. The V-rib is longer than in most species and nearly reaches the dome.

\section{The papillosa group}

Mallomonas papillosa Harris \& Bradley (1957) (Pl. 5, figs. 30, 31; compare Harris \& Bradley (1957), pl. IV, fig. 9, and text figs. H-M)

This species was described in 1957 with the use of the optical microscope and replicas only. A description is not complete without a direct electron micrograph, and we are therefore publishing one here (Pl. 5, fig. 31). It was obtained from material collected at the type locality. A new figure of bristles is added, also from the same locality (Pl. 5, fig. 30). The electron micrograph of the scale shows, in addition to the features already known from the replicas, that there is a small group of cavities, pits, or perforations at the proximal end of the shield under the hood, but none is seen anywhere else on the scale. The bristles in the new figure are strongly serrate and about three times as long as the larger scales (allowing for the difference in the magnification). Those of our 1957 micrographs are frequently smooth, as in the published 
figure, and sometimes less than twice as long as the scale. We possess, however, micrographs showing all variations between the published figures of 1957 and that of this paper, both as regards length and degree of serration.

There are a number of forms of $M$. papillosa which differ from the type and from each other in the arrangement of the papillae on the shield, the presence of papillae instead of ribs on the distal end of the flange and the degree of serration of the bristles. We give figures of one form, f. annulata (Pl. 5, figs. 32, 35.) The papillae are arranged in rings at the proximal end of the shield, the distal end of the flange is marked by papillae instead of parallel ribs, and the bristles are smooth. The direct electron micrograph shows oblique rows of cavities crossing the whole shield and scattered cavities also on the flange. This form was found only in the electron micrograph of a slide picked out from a store of dried slides which had been identified as $M$. papillosa. No special study had been made of the unbroken cell. It may well be that it should have varietal rank. Locality, Ewhurst, Hants.

Scale structure Mallomona acaroides, M. intermedia and M. monograptus

The shield, in all these species, shows minute depressions on both inner and outer surface replicas and the direct electron micrograph shows cavities. As the depressions and cavities are similarly placed we are satisfied that they represent the same minute perforations through the silica substance which are enlarged in the interior of the scale. The struts and ribs seen in the electron micrographs are built on to the outer surface of this perforated silica plate.

The replicas of the inner and outer surface of $M$. lelymene do not show any perforations or depressions though the direct electron micrograph shows cavities. It is possible that these inner and outer surfaces are not perforated in this species, or merely that the perforations are too small to see in our preparations. All we can assert, therefore, is that the shield possesses internal cavities that may prove to be perforations at certain stages or in better preparations. The struts shown in the direct electron micrograph of the rim of both shield and flange are internal, no sign of them being visible on either outer or inner surface.

Our direct electron micrographs of $M$. flora and $M$. cratis, like those of $\boldsymbol{M}$ lelymene, show internal cavities, but the replicas give no clear evidence of perforations of the inner and outer surfaces. The $V$-rib and transverse ribs are built on the outer surface of the scale and three of our electron micrographs (Figs. 23, 26 and 18), can be interpreted as a series showing their development. The V-rib and flange margin seem to be built first and the transverse ribs added later, starting from the dome. The radial struts and dome ornamentation appear first in Fig. 26. The V-rib and flange margin are more prominent in Fig. 26 than in Fig. 23, while the teeth in the angle of the V-rib are first apparent in Fig. 18.

$M$. striata var. serrata shows no perforations in the replicas of its scales, either on the inner or outer surface, nor do most of the direct electron micrographs of either the type or the variety show internal cavities all over the scale. We have, however, a few unpublished electron micrographs of immature 
scales which do show such cavities. All the direct electron micrographs show a group of rather large cavities, or pits in the angle of the $V$-rib.

In $M$. papillosa the scale replicas show no perforations in the inner or outer surface, and our direct electron micrographs show no cavities or pits except in the angle of the V-rib. M. papillosa var. annulata does show a clear pattern of internal cavities in the direct electron micrograph of the scale.

\section{SERIES II. PLANAE}

Mallomonas multiunca Asmund (Figs. 21-23; Pl. 5, figs. 33, 34, 36 and 37)

History. This species was described in $\mathbf{1 9 5 6}$ from material found in a small 'polyhumic' pool in an acid peat bog in Denmark. In 1959 further material was described. Some of this came from eutrophic ponds and differed in certain respects from the type.

A. multiunca Asmund has been found from a few localities in South Berkshire. These samples agree very closely with the material described by Asmund in 1956 with the use of both optical and electron microscope. Like hers, this material was found in small pools on acid peat, surrounded by bushes, in early autumn. The cells are sometimes spherical as well as ovoid, the spherical ones being cells about to produce cysts. In all other respects they are like Asmund's specimens.

The cyst, which has not been previously recorded, is spherical, smooth or finely punctate, with a small pore and without a rim. The direction of the pore could not be seen. The mother cell fits closely round the cyst, and, in our experience, retains its bristles.

Dimensions. Cell $14-22 \mu \times 8.12 \mu$, cyst $15 \times 13 \mu$ or $15 \mu$ diameter. Individual cell measurements, $19 \times 9 \mu, 17 \times 7 \mu$ and $15 \times 12 \mu$ (as cyst formation approached).

Variations. Replicas of $M$. multiunca scales were figured in Harris \& Bradley (1957; pl. IV, fig. 7). These scales were found in eutrophic, dung contaminated water under trees, together with the scales of $M$. heterospina, Lund. While they clearly belong to the species $M$. multiunca they differ from the type in certain respects but agree closely with the eutrophic form described by Asmund in 1959. The cells are somewhat larger than the type, most of the scales are larger, marked by a greater number of large annular thickenings and the bristle hook is longer and more slender. A few small scales are often found with these large ones. One is shown in Pl. 5, fig. 37. It has three annular thickenings and is intermediate in size between the large scales shown in our 1957 publication and the scales of $M$. multiunca type shown in Pl. 5, figs. 33 and 36. While the type occurs in autumn this eutrophic form occurs in winter and spring. Cysts of this form (not confirmed with the electron microscope) were found in a woodland pool ( $\mathrm{pH} \mathrm{6.8)} \mathrm{in} \mathrm{February.} \mathrm{The} \mathrm{cyst} \mathrm{is} \mathrm{rather} \mathrm{larger}$ than that of the type, ovoid, smooth with anterior pore, situated in a small flattened area. The cyst is contained in its mother cell which is covered with bristles, nearly all bearing hooks.

Dimension of cyst. $19 \times 17 \mu$. 
Scale structure. The outer surface has conspicuous depressions arranged in lines which follow the shape of the thickened ridges on the scale, both the outer and the inner circles (Pl. 5, figs. 36, 37). The inner surface of the scale also shows depressions arranged in a similar pattern (Pl. 5, fig. 34) and the direct electron micrograph shows clear cavities in the matrix of the scale which also have a similar pattern (Pl. 5, fig. 33). We consider that all these pictures are different representations of perforations which pass through the whole thickness of the scale. This scale appears to have no internal layer. Replicas of the outer surface show some papillae situated chiefly at the distal end of the scale. The electron micrograph show these papillae as dark dots, sometimes in rows, sometimes singly between the perforations. Both forms of $M$. multiunca are alike in their scale structure.

\section{Mallomonas oviformis Nygaard (Figs. 24-26, Pl. 5, figs. 38-41)}

History. M. oviformis was described by Nygaard (1949) with the optical microscope; Asmund (1959) added direct photographs with the electron microscope. Our observations agree closely with Nygaard's and Asmund's, but our maximum dimensions are larger. Our replicas of the scale add to the understanding of its structure and we also describe the cyst, not hitherto recorded.

The cyst is ovoid with a small pore lacking a rim. It looked shagreened, but this may have been due to the markings on scales of the mother cell

\section{Legends for Figs. 18-44}

Figs. 18-44. 18. Mallomonas cratis, mature cell showing bilobed chromatophore and contractile vacuoles, $\times 1000$. 19. M. cratis, scale and bristle, $\times 2000.20 . M$. cratis, cyst showing two chromatophore lobes, $\times 1000$. 21. M. multiunca with cyst, the refractive bristle tips form the ring round the mother cell. 22. M. multiunca, scale showing two large, and faint, annular markings, and bristles with hook, $\times 2000$. 23. M. multiunca, mature cell showing two chromatophore lobes, leucosin body and contractile vacuoles, $\times 1000$. 24. $M$. oviformis, mature cell showing bilobed broad twisted chromatophore and contractile vacuoles, $\times 1000$. 25. M. oviformis, scale, showing proximal rim faintly marked, $\times 2000$. 26. M. oviformis, cyst in mother cell which shows signs of disintegrating, some bristles are missing and some scales loose, $\times 1000$. 27. M. adamas, scale showing markings, $\times 2000$. 28 . M. adamas, mature cell showing outline of some scales on its surface, $\times 1000$. 29. $M$. adamas, cyst in disintegrating mother cell, $\times 1000$. 30. M. allorgei, cyst, $\times 1000$. 31. M. allorgei, mature cell showing bilobe chromatophore and contracile vacuoles, $\times 1000.32$. M. allorgei, scale showing markings, $\times 2000$. 33. M. pumilio var. silvicola, cyst in mother cell, scales are shown on the surface of the mother cell at the anterior end, $\times 1000.34 . M$. pumilio var. silvicola, anterior scale, $\times 2000$. 35. M. pumilio var. silvicola, part of cyst wall, $\times$ about 3000 . 36. M. pumilio var. silvicola, mature cell showing lobes of the H-shaped chromatophore at the side of the cell, leucosin body, and contractile vacuoles, $\times 1000$. 37. M. phasma, mature cell showing nucleus, some refractive granules, leucosin body and contractile vacuoles, $\times 1000$. 38. M. phasma, cyst in mother cell, showing leucosin, body refractive granules, two chromataphore lobes; some small scales are shown at the rear of the mother cell, $\times 1000$. 39. M. phasma, body scale, $\times 2000$. 40. M. phasma, anterior scale, $\times 2000$. 41. M. mangofera, mature cell showing bilobed chromatophore and contractile vacuoles, $\times 1000$. 42. $M$. mangofera, cyst in mother cell, $\times 1000$. 43. $M$. mangofera, anterior scale, $\times 2000$. 44. M. mangofera, body scale, $\times 2000$. 
enclosing it. The direction of the pore was not clear. Only two cysts have been found. The scales of the mother cell drop away soon after the cyst has been formed and the cyst is not recognizable with any certainty without them.

Dimensions. Cell $20-32 \mu$ (rarely $42 \mu$ ) $\times 12-20 \mu$, scales $5-7 \mu \times 3-4 \mu$, bristles 8-20 $\mu$, cyst 18-20 $\mu$.
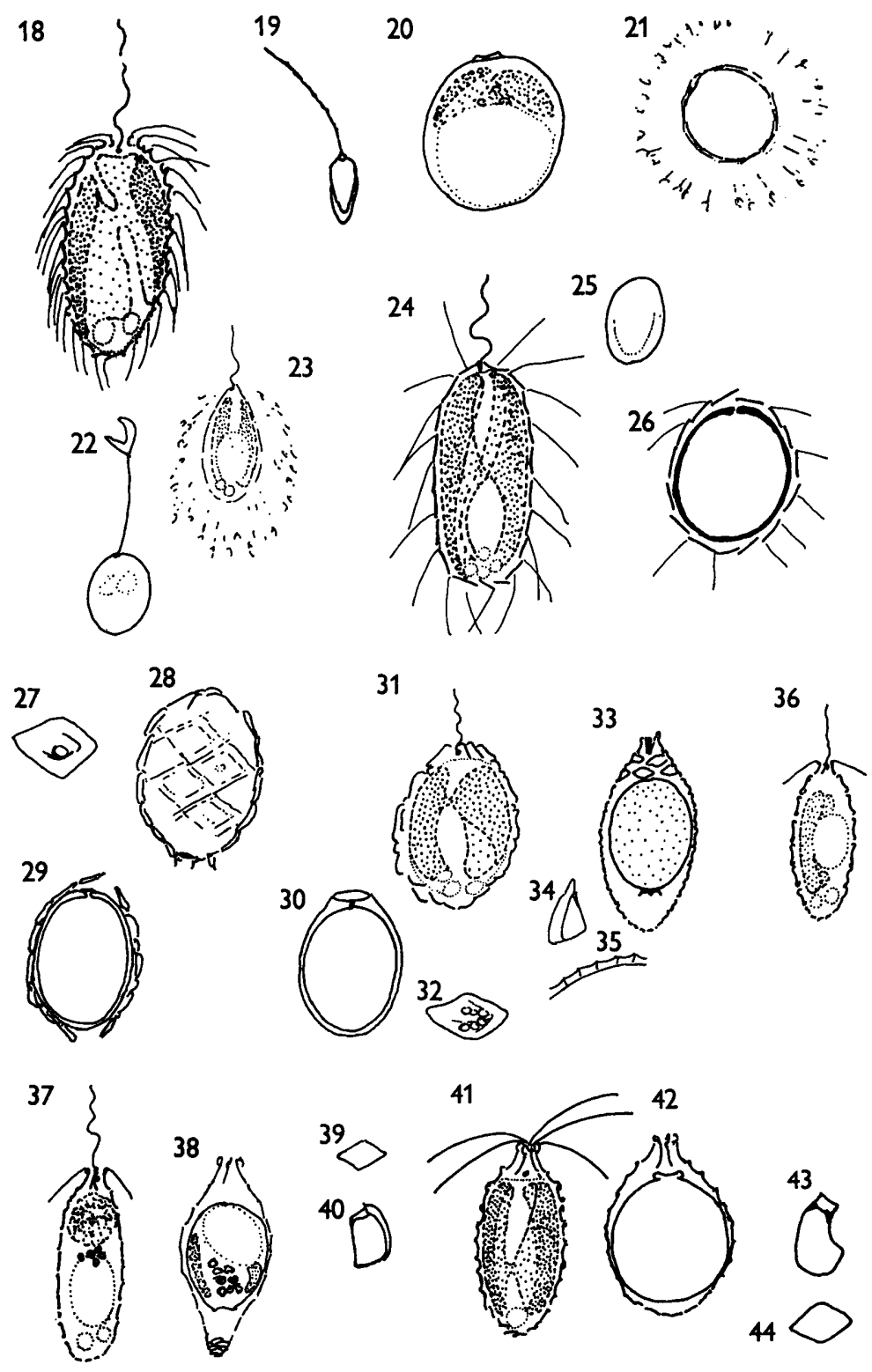

Figs. 18-44. For legend see opposite page. 
Occurrence. M. oviformis is common, in the neighbourhood of Reading, in eutrophic ponds and ditches from November until the following March. The cysts were found in January (in the bottle), and in March.

Scale structure. The outer surface of the scale is papillose except for a semicircular smooth area inside the proximal rim (Pl. 5, fig. 40). The inner surface, not figured here, shows rather obscure, close but irregularly scattered depressions almost certainly representing perforations through that surface. There is an internal layer with a reticulate structure which is exposed in the immature scale shown in Pl. 5, fig. 39. The direct electron micrograph (Pl. 5, fig. 38), shows a pale-coloured semicircular area which corresponds to the smooth area (Pl. 5, fig. 40), and a dark portion, in which the papillae may be seen as dark dots, corresponding to the papillose area. The greater part of the scale, except at the outer edge, is covered by dark twisting 'vermiform' lines described by Asmund. These are separated from each other by similar pale-coloured lines containing white dots which must be thin places in the silica. This appearance is not explained by the features in the replicas of the inner or outer surface and must be due to internal thickenings. The white dots, in Pl. 5, fig. 38, are too close to be entirely accounted for by the cavities of the reticulum shown in Pl. 5, fig. 39, and are of unequal size. They may, however, represent both those cavities and the perforations of the inner surface superimposed. The black vermiform lines of Pl. 5, fig. 38, are not completely explained by anything that we can see in Pl. 5, fig. 39, either alone or combined with other replicas.

\section{SERIES III. QUADRATAE}

Mallomonas adamas sp.nov. (Figs. 27-29; Pl. 6, figs. 42-44 and 50)

Diagnosis. Cellula ovoides rotundata, sine setis sed post cuspibus parvis quinque armata. Squamae sine cupola, sine margine. Squamae corporis aliquantum ovalis, asymetricalis, proxime rotundatae, distale obtusae. Squamae antici et postici prope rotundatae. Squamae omnes cum V-costa lata et leve, distale papillosae et cavo uno (vel plures) magno et profundo ad limbum partis papillosae. Squamae posteriores cum jugo prominente inter partes leves et papillosos. Cystum ovale, leve; porus parvus sine labro.

Dimensiones. Cellula 13-27 $\mu \times 11-17 \mu$, squamae corporis 6-9 $\mu \times 3 \frac{1}{2}-5 \mu$, cystum 13-20 $\mu \times 13-15 \mu$.

English diagnosis. Cell round oval without bristles but with five small projections at rear. Scales without dome or flange. Body scales somewhat oval, asymmetrical, rounded at proximal end, bluntly pointed at distal end. Anterior and posterior scales nearly round. All scales having smooth V-rib, papillose at distal end, one or more large deep depressions at edge of papillose area. Rear scales have strongly projecting ridge between smooth and papillose areas. Cyst oval, smooth; pore small, without rim.

Additional characters. The inner surface of the scale does not appear to be striated, as in $\boldsymbol{M}$. allorgei, and we have no evidence of perforations in this surface. The scales we studied were too dense for direct electron micrographs. 
The name, 'adamas' = 'diamond' is from the appearance of the empty cell armour which looks like a many-faceted jewel.

Occurrence. M. adamas is fairly common in pools on acid peat, in woodland or on gravel where the water is not contaminated by animal dung, and has been found in ten localities near Reading. It seems to occur for short periods at any time of year, but we do not know what conditions favour its development. Only two cysts have been found, one in January and the other in June. Type from Westwood, Sunningdale, Nat. Grid 494/167.

Pl. 6, fig. 42, shows a portion of the unbroken scale armour. The overlap of the scales is such that the whole of the V-rib and most of the smooth part of the scale is hidden, only the papillose part being exposed.

Pl. 6, figs. 43, 44, and 50, show the outer surface of scales from different parts of the cell. None of these are clearly perforated, though some of the papillae in Fig. 50 seem to show a hole in their apex. The inner surface shown in Fig. 44 shows no evidence of perforations or striations. This may be due to the imperfection in the preparation and more preparations require to be seen before any conclusion is drawn.

Mallomonas allorgei (Deflandre) Conrad (1933) (Figs. 30-32; Pl. 6, figs. 45-49)

$M$. allorgei has not been recorded for Britain, but we have found it frequently in a variety of ponds and lakes from December until the following April. Some of the ponds are on acid peat and others on farm land. Cysts were found in April.

Our specimens agree closely with those described by Deflandre in all features visible with the optical microscope. It has not previously been studied with the electron microscope.

Scale structure. The scales of $M$. allorgei are thinner than those of $M$. adamas and gave adequate direct electron micrographs to supplement the information obtained from replicas. The body scales are rounded rhomboidal and the flagellum scales broadly oval. The outer surface of both types is ornamented by about six deep large depressions usually arranged in two converging rows in the proximal portion of the scale (P1. 6, fig. 46). The pattern, however, is sometimes irregular and few, or rarely no depressions may be present. This is thought to occur in juvenile scales only, but further investigation is needed. The outer surface of the scale, except for the V-rib, has regularly spaced papillae about $0.35 \mu$ apart. The inner surface of the scale shows delicate longitudinal striations $0 \cdot 1 \mu$ apart along which it is possible to distinguish minute perforations $0.07 \mu$ apart. The direct electron micrograph gives a different picture. The large depressions are seen to be thin areas and, in our electron micrographs, nothing can be seen of the papillae of the outer surface. The substance of the scale, apart from the large depressions, shows a honeycomb, or reticulate, structure, with cavities about $0 \cdot 1 \mu$ apart. In the large depressions there are tiny perforations $0.07 \mu$ apart in rows $0.1 \mu$ apart, thus corresponding to those seen in the replica of the inner surface. With more difficulty the tiny perforations of the inner surface can also be seen through the honeycomb structure. The nature of the scale can thus be supposed to be 
made up of three layers, a basal plate showing perforations $0.07 \mu$ apart in rows $0 \cdot 1 \mu$ apart, a honeycomb layer with cavities $0 \cdot 1 \mu$ apart which is covered by a smooth thin roof on which papillae are built, $0 \cdot 35 \mu$ apart. Some direct electron micrographs seem to suggest that these papillae have a hole down the middle but this is doubtful. Certain immature scales have been seen in which the honeycomb layer is exposed without any roof (Pl. 6, fig. 45).

Sometimes one or two immature scales are seen in a cell armour otherwise composed of mature normally developed scales. We have such a micrograph which lack of space forbids us to publish. Theremay be a connexion between these immature scales and the 'shedding of scales' described in Harris (1953, p. 97).

Plate. 6, fig. 49, shows the complete armour of a cell. All its scales are fully formed with the outer surface bearing papillae. The anterior scales (at the bottom of the figure) are seen to be of the normal size, if we allow for the fact that the $V$-rib is hidden by the overlapping scale, but the pattern of large depressions is irregular. The scales become smaller as they approach the posterior end and the number of large depressions becomes less, the rear scales being very small and without depressions; we believe this to be a juvenile cell.

Comparison. The three species of this group, $M$. adamas, $M$. allorgei and $M$. lychenensis, are the only species we know of the group. They resemble each other closely and look very different from all other groups owing to their thick, closely fitting, convex scales. M. lychenensis is distinguished by having anterior bristles, although these may sometimes be absent, and in having scales marked by two rows of deep depressions which when seen with the light microscope take the shape of a pair of lips. M. allorge $i$ has scales marked by two rows of deep depressions which extend only half way across the scale, and are sometimes irregular. They are much less conspicuous in the living cell than the marks on the lychenensis scale. M. adamas has no marks on the scales which are perceptible with the light microscope and it is the only species to have rear projections. Thus the species are easy to distinguish in the living condition. The electron micrographs of scales have been described in detail. They elucidate the structure visible in the optical microscope, and also show the scales of $\boldsymbol{M}$. allorgei are intermediate between those of $\boldsymbol{M}$. lychenensis and $\boldsymbol{M}$. adamas. A certain number of scales of $M$. lychenensis would not be easy to distinguish, in isolation, from normal scales of $\boldsymbol{M}$. allorgei and similarly, some of the scales of $\boldsymbol{M}$. allorgei are very like typical scales of $\boldsymbol{M}$. adamas.

\section{SERIES IV. TORQUATAE}

Mallomonas pumilio var. silvicola (Figs. 33-36; Pl. 7, figs. 55, 58, 61 and 62)

Diagnosis. A typo differt in squamis cum poris sparsis incompositis, vel in ordinibus brevibus inequalibus, in loco circulorum. Cystum differt in forma globosiore et in supifice papillosa et in labro prominente poris.

Dimensiones. Cellula $10-28 \mu \times 7-15 \mu$, squamae collaris longitudinis $3 \mu$, setae 6-8 $\mu$, cystum $13-17 \mu$.

English diagnosis. Differs from the type in having scales with pores which are arranged irregularly, often in short irregular rows, instead of circular 
groups. The cyst differs in being papillose, more nearly spherical and having a prominent cup round the pore.

The name 'silvicola' $=$ 'an inhabitant of woods' refers to its frequent occurrence in woods.

Occurrence. It has been found in woodland pools and on acid peat ( $\mathrm{pH} \mathrm{5.5-}$ 6.5). It may occur in small lakes or in ponds which dry up during summer and its appearance and duration seem to depend on other factors than temperature. It occurs after a period of heavy rain at any time of the year. Its life cycle is completed in a short time, 2 or 3 weeks, after which it encysts and disappears from the pond. It may reappear several times during one year and has been found in most months. Its occurrence thus differs from that of the type which is only found in winter and spring, appears once in a pond and does not reappear, after encystment, until the following year.

Comparison. It is difficult to distinguish $M$. var. silvicola from the type, M. pumilio, without the help of the electron microscope unless the cyst is present. Var. silvicola is slightly larger than the type but their range of size overlaps. The cyst is rounder than that of the type, has a more prominent rim and is covered with small raised dots. With the electron microscope the scales are easily distinguished, $M$. silvicola having scattered pits while the type has pits arranged in circular groups and surrounded by a raised border.

M. pumilio (Pl. 7, figs. 60, 63) and $M$. var. silvicola are the two smallest that we know of the group. Both have similar spikes on the rear end which are barely visible with the optical microscope. This distinguishes them from $M$. doignonii Bourrelly, which has a larger cell and in which the rear spikes are visible even in small and immature individuals.

A number of species belonging to the Torquata Group have been described from different parts of Europe, with the optical microscope. They look, from the figures given, like $M$. pumilio and $M$. pumilio var. silvicola but show small distinct differences. They may show greater differences when examined with the electron microscope or they may prove to be closely similar to $M$. pumilio and its variety. Until we have the evidence of the electron microscope it seems less confusing to give a new name to the fully described species and its variety instead of using the older names without any certainty of identity, although this has been a common practice in the past. Interesting problems of distribution depend on the accurate naming of species since some species and varieties have a very wide range of distribution in the world, apparently occurring both in Japan and Europe.

$M$. anglica Carter (1937) resembles $M$. pumilio rather than var. silvicola in size (8-20 $\mu \times 5-8 \mu)$, but it possesses no bristles at any stage of its development and its cyst is spherical, or nearly so, smooth and without a rim.

M. marjorensis Skuja (1918) resembles $M$. pumilio in size $(9-20 \mu \times 5-8 \mu)$ and in its cyst except for the strongly marked rim to the cyst. The figures show long anterior bristle, about $8 \mu$ long, and the scales are slightly smaller than in $M$. pumilio.

$M$. tenuis Conrad (1938). The cell is only $12-17 \mu \times 6-8 \mu$ and is spindleshaped rather than ovoid. The cyst has a conspicuous flattened rim. 
M. limnicola Lund (1942) is smaller than M. pumilio or var. silvicola and unlike these two is said to be somewhat flattened at one side.

The following species are small ones belonging to the Colares Group but are too little known for comparison. Haber-Pestalozzi gives references.

M. playfairi Conrad (1927, 1933).

M. alkanoviana Conrad (1933).

M. oblongispora Lemmermann (1903).

Mallomonas phasma sp.nov. (Figs. 37-40, Pl. 7, figs. 51-53)

Diagnosis. Cellula ovoides, post rotundata, ante apta collari quinque squamarum prominentium et setas ferentium. Chromatophoros ferme non cernenda, si cerni potest, pallidissima litterae $\mathrm{H}$-forms, latere uno cellulae. Squamae corporis rhomboides, squamae collaris ovales-oblongue cum cupola, asymetricae, latus alterum forte convexum, latus alterum parvum concavum, et transverse costatum prope cupolam. Cupola levis vel papillosa. Squamae omnes margine prominenti uno vel duobus ordinibus pororum, et regione interiore poris eaque sparsis. Setae leves attenuata, pede lato complanato. Cystum ovatum, porus parvus, posterior, labro exiguo.

Dimensiones. Cellula 20-31 $\mu \times 7-10 \mu$, squamae corporis $3 \times 1 \frac{1}{2} \mu$, squamae collaris $5 \times 3 \mu$, setae 7-8 $\mu$, cystum 14-16 $\mu \times 11-13 \mu$.

English diagnosis. Cell ovoid, rear end rounded, anterior with collar of about five forward pointing scales usually bearing bristles. Chromatophore usually invisible, if visible very pale, $\mathrm{H}$-shaped, at one side of cell. Body scales rhomboidal, collar scales oblong oval with dome, asymmetric, one side strongly convex, other side slightly concave, transversely ribbed near dome. Dome smooth or papillose. All scales with raised margin, having one or two rows of perforations and inner region covered with evenly spaced perforations. Bristles smooth, tapering with broad flattened foot. Cyst ovoid, pore small, posterior with slight rim. The name 'phasma' = 'ghost' refers to the lack of colour and consequent difficulty in seeing the cell.

Occurrence. M. phasma is found in shallow pools on acid peat, often near Sphagnum. It has been recorded in each month from January to July. The cysts occurred in March in a bottle of water collected a fortnight earlier. This species seems to tolerate both heat and cold. It was found in a nearly dried up pond in June 1951 and under ice in February 1955. The type occurred at Burnt Common, Mortimer, Nat. Grid. 462/174.

Comparison. M. phasma differs from all other species of the Torquatae by the apparent lack of a chromatophore, or when occasionally the chromatophore is visible, by its extreme paleness. M. pallida Conrad is another species of extreme paleness but it is a different shape and bears bristles on the rear half of its cell.

Mallomonas mangofera sp.nov. (Cf. unnamed figure, Takahashi, 1959). (Figs. 41-44; Pl. 7, figs. 54, 56, 57)

Diagnosis. Cellula ovoides, post rotunda ante collari apta squamarum quinque ad septem prominentium, setas longas conspicuas arcuatas ferentium. Squamae corporis rhomboides, squamae collaris elongatae oblique flectae, 
cupola lata papillosa. Squamae omnes concavae, marginibus prominentibus profunde sulcatis, margo squamarum collaris prope cupolam absens. Superficies squamarum omnium papillis seque sparsis, sed post margines leves. Setae leves, attenuatae pede lato complanata. Cystum rotundatum-ovatum, leve, porus anterior, labrum vel latum et conspicuum.

Dimensiones. Cellulae 14-30 $\mu \times 7-12 \mu$, squamae collaris 5-7 $\mu \times 3 \mu$, squamae corporis $4 \times 2 \cdot 5 \mu$, setae $13-17 \mu$, cystum 18-20 $\mu \times 17-18 \mu$.

English diagnosis. Cell ovoid, rear end rounded, anterior with collar of five to seven forward pointing scales bearing long curved bristles. Body scales rhomboidal, collar scales elongated, curves to one side, with a broad papillose dome. All scales possess deeply grooved margins, margin of collar scales absent near dome. Surface of all scales covered with evenly spaced papillae but proximal margins smooth. Bristles smooth, tapering with broad flattened foot. Cyst round ovoid, smooth, pore anterior, rim slight or broad and conspicuous.

The name 'mangofera' refers to the mango-like shape of the anterior scales.

Occurrence. M. mangofera was found in one locality in a small pond on acid peat in April near Hook, Nat. Grid 472/155, in large numbers. The cysts occurred in the bottle about a week later.

Additional characters. The rear end of the cell may show some minute projections. In examining the scale of the disintegrated armour a few are often found with a small projection near the distal end. Such a scale is seen at the top right-hand corner of $\mathrm{Pl}$. 7, fig. 57 .

\section{Scale structure in the torquatae}

In $M$. phasma the replica of the outer surface (Pl. 7, figs. 51, 52) show conspicuous pits which correspond to the cavities seen in the direct electron micrograph (Pl. 7, fig. 53). The replica of the inner surface (Pl. 7, fig. 52), left side, shows pits, which correspond in their spacing to those of the outer surface, but are smaller. Thus the scale is a perforated plate with border, the perforations being smaller on the inner surface than farther outwards. They do not seem to be constricted at the outside. There is no differentiation into three layers.

In $M$. mangofera the replica of the outer surface shows papillae but no pits, except possibly in the apex of the papillae, and the inner surface is also without distinct pits or depressions. The direct electron micrograph shows the papillae as dark dots, and also a few scattered cavities which do not coincide with the papillae. Thus the scale appears to be an imperforate plate of silica containing a few scattered cavities and on this plate papillae and the border have arisen. This scale also is without three distinct layers.

The replica of the outer side of the scales of $M$. pumilio and pumilio var. silvicola show clearly marked pits, in groups in the type, scattered in the variety (Pl. 7, figs. 63, 62). In both cases these correspond with the cavities seen in the direct electron micrographs ( $\mathrm{Pl}$. 7, figs. 60, 55). The replica of the inner surface of var. silvicola does not show any clear pits or depressions. The 
scale of var. silvicola, therefore, seems to consist of a simple imperforate silica plate on which a reticulum of silica has been built. We have no replica of the inner side of a scale of $M$. pumilio but the immature scale shown at the top of Pl. 7, fig. 63, which shows a thin imperforate silica plate suggests that the sculpturing of the scale of $\boldsymbol{M}$. pumilio is built up as we have described for the scale of var. silvicola. In this species also there is no distinct internal layer.

In addition to the species of the Torquata group just described, we would like to mention another species which we examined with replicas, in 1957. We called the species $M$. coronata Permain \& Vinnikova, 1955, syn. M. doignonii Bourrelly, 1951. This was a mistake; the name should have read $M$. coronifera Matv., 1941, as interpreted by Permain \& Vinnikova, 1955. Our material had been seen by Bourrelly and identified as $M$. doignonii which we believed was synonymous with $M$. coronifera. Since 1957 we have obtained a copy of Matvienko's paper from Russia. We find that the three descriptions, by Matvienko, by Bourrelly and by Permain \& Vinnikova differ from each other in certain points which might be a matter of interpretation or might be a fundamental difference. Fott's recent paper (1959) gives clear evidence that $M$. doigonii Bourrelly, and the Czechoslovakian material of $\boldsymbol{M}$. coronifera are different species. The pattern of ridges is very much finer and the ridges more numerous in the scale of $\boldsymbol{M}$. coronifera than in that of $M$. doignonii. It would be interesting to see electron micrographs of Matvienko's Ukrainian material, $M$. coronifera type specimens. Our material is $\boldsymbol{M}$. doignonii.

The authors wish to thank Professor J. M. R. Cormack of Reading University for his help with the Latin diagnoses and Miss Berit Asmund of Denmark for sending us slides and electron micrographs of Danish material for comparison. One author (D.E.B.) would like to thank Dr T. E. Allibone, F.R.S., Director of the Research Laboratory, Associated Electrical Industries Ltd., for permission to publish this paper.

\section{REFERENCES}

Asmund, B. (1955). Electron microscope observations on Mallomonas caudata and some remarks on its occurrence in four Danish lakes. I. Bot. Tidsskr. 52, 163.

Asmund, B. (1956). Electron microscope observations on Mallomonas species. and remarks on their occurrence in some Danish ponds. II. Bot. Tidsskr. 53, 75.

Asmund, B. (1959). Electron microscope observations on Mallomonas species and some remarks on their occurrence in Danish ponds and lakes. III. Dansk. bot. Ark. 18, 3.

Bourrelly, P. (1957). Recherches sur les Chrysophycées. Rev. algol. Mémoire hors Ser. I, p. 183.

Bradley, D. E. (1954a). Evaporated carbon films for electron microscopy. Brit. $J$. appl. Phys. 5, 65.

Braduey, D. E. (1954b). An evaporated carbon replica technique for use with the electron microscope, and its application to the study of photographic grains. Brit. J. appl. Phys. 5, 96.

BradLey, D. E. (1955). A simple adaptation of carbon replica technique for the examination of selected areas in the electron microscope. Brit. J. appl. Phys. 6, 430.

Conrad, W. (1927). Essai d'une Monographie des genres Mallomonas Perty (1851). et Pseudomallomonas Chodat. (1920). Arch. Protistenk. 59, 1926. 
Conrad, W. (1933). Revision du Mallomonas Perty (1851) incl. Pseudomonas Chodat. (1920). Mém. Mus. Hist. nat. Belg. 56, 1.

Deflandre, G. (1932). Contribution à la connaissance des flagellés libres. I. Ann. Protist., Paris, 3, 220.

Fotr, B. (1955). Scales of Mallomonas observed in the electron microscope. Preslia, $27,280$.

Fort, B. (1957). Taxonomie der mikroskopischen Flora einheimischer Gewässer, Preslia, 29, 278.

Fotr, B. (1959). Das Phytoplankton der Talsperre bei Sedlice. Preslia, 31, 213.

Harris, K. (1953). A contribution to our knowledge of Mallomonas. J. Linn. Soc. (Bot.), 55, 88.

HARris, K. (1958). A study of Mallomonas insignis and Mallomonas akrokomos. J. gen. Microbiol. 19, 55.

HaRRIS, K. \& BRADLeY, D. E. (1957). An examination of the scales and bristles of Mallomonas in the electron microscope, using carbon replicas. J. R. micr. Soc. 76, 37.

Harris, K. \& Bradley, D. E. (1958). Some unusual Chrysophyceae studied in the electron microscope. J.gen. Microbiol. 18, 71.

Kisselew, J. A. (1931). Zur Morphologie einiger neuer und seltener Vertreter des pflanzlichen Mikroplankton. Arch. Protistenk. 3, 237.

Lund, J. W. G. (1942). Contributions to our knowledge of British Chrysophyceae. New Phytol. 41, 274.

NygaARD, G. (1949). Hydrobiological studies on some Danish ponds and lakes. Part 2. Biol. Skr. 7, 117.

Pascher, A. (1913). Flagellatae II. Süsswasserflora Deutschlands, Österreichs und der Schweiz. 2, 31. Jena: Verlag von Gustav Fischer.

Skuja, H. (1939). Beitrag zur Algenflora Lettlands. II. Acta Hort. bot. Univ. latv. XI/XII, 41, Ed. 30, III.

Takahashi, E. (1959). Studies on the genera Mallomonas, Synura, and other plankton in fresh water, by the electron microscope, I. Bull. Yamagata Univ. (Agric. Sci.), 3, 117.

Woloszynska, J. (1939). Die Algen der Tatraseen und Tümpel, 4. Mallomonas Arten in den Tatraseen. Acta Soc. Bot. Polon. 16, 29.

\section{EXPLANATION OF PLATES}

\section{Plate 1}

Fig. 1. Mallomonas intermedia var. gesticulans, replica of nearly complete cell armour. The anterior end is to the right, $\times 3000$.

Fig. 2. M. acaroides, direct micrograph of a bristle tip, $\times 6,700$.

Fig. 3. M. acaroides, replica of a bristle tip. $\times 6700$.

Fig. 4. M. acaroides, replica of the inner side of a scale, $\times 6700$.

Fig. 5. M. acaroides, replica of the outer side of a scale, $\times 6700$.

Fig. 6. M. intermedia, form, direct electron micrograph of an elongated bristle tip, $\times 6700$.

Fig. 7. M. acaroides, direct electron micrograph of a scale, $\times 6700$.

Fig. 8. M. intermedia, direct electron micrograph of juvenile scales, without domes from the rear of a cell, $\times 6700$.

Fig. 9. M. intermedia var. gesticulans, replica of two bristles, showing mature folded tip and an undeveloped tip, $\times 10,000$.

Fig. 10. M. intermedia var. gesticulans, group of bristles showing variations in bristle tip and serration. $\times 6700$.

Plate 2

Fig. 11. Mallomonas lelymene, replica of inner side of a scale, $\times 6700$.

Fig. 12. M. lelymene, replica of the outer side of a scale, $\times 6700$.

Fig. 13. M. lelymene, direct electron micrograph of a scale, $\times 6700$.

Fig. 14. M. lelymene, replica of a bristle, $\times 6700$. 
Fig. 15. M. monograptus, replica of the inner side of a group of scales, $\times 6700$.

Fig. 16. M. monograptus, replica of the outer side of a group of scales, the upper left scale is juvenile and has no dome, $\times 6700$.

Fig. 17. M. monograptus, direct electron micrograph of two scales, one of which is juvenile and has no dome, $\times 6700$.

\section{Plate 3}

Fig. 18. Mallomonas cratis, replica of a scale and parts of neighbouring scales, $\times 10,000$.

Fig. 19. M. striata var. serrata, direct electron micrograph of a scale, $\times 10,000$.

Fig. 20. M. striata var. serrata, replica of a group of scales, one showing the outer side and three showing the inner side, $\times 10,000$.

Fig. 21. $M$. flora, direct electron micrograph of a scale, $\times 10,000$.

Fig. 22. $M$. flora, replica of two bristles and part of the inner side of a scale, $\times 10,000$.

Fig. 23. $M$. cratis, direct electron micrograph of an immature scale, $\times 10,000$.

Fig. 24. $M$. cratis, direct electron micrograph of a bristle, a small part of the base and tip have been cut off, $\times 10,000$.

Fig. 25. $M$. flora, replicas of a group of scales, outer sides and some portions of inner sides are showing as well as parts of bristles, $\times 10,000$.

Fig. 26. $M$. cratis, direct electron micrograph, a slightly immature scale, $\times 10,000$.

Fig. 27. $M$. cratis, replica of a portion of the unbroken cell armour, $\times 6,700$.

Fig. 28. $M$. flora, replica of a portion of the unbroken cell armour, $\times 6700$.

\section{Plate 4}

Fig. 29. Mallomonas striata var. serrata, replica of an unbroken cell with bristles. Some scales of $M$. papillosa are intruding at the top left, $\times 10,000$.

\section{Plate 5}

Fig. 30. Mallomonas papillosa, electron micrograph of bristles, $\times 6700$.

Fig. 31. M. papillosa, direct electron micrographs of two scales, $\times 10,000$.

Fig. 32. M. papillosa forma annulata, direct electron micrograph of scales and bristles, $\times 10,000$.

Fig. 33. M. multiunca, direct electron micrograph of a scale with attached bristle, $\times 6700$.

Fig. 34. M. multiunca, replica showing the inner side and parts of the outer side of scales and two bristle hooks, $\times 6700$.

Fig. 35. M. papillosa forma annulata, replica showing a group of scales from the anterior end of body, both with and without a dome, and one small juvenile rear scale without a dome, $\times 10,000$.

Fig. 36. $M$. multiunca replica showing the outer side of a scale and the shaft of one bristle and hook of another, $\times 6700$.

Fig. 37. M. multiunca, replica of some of the smaller scales of the eutrophic form, $\times 6700$.

Fig. 38. $M$. oviformis, direct electron micrograph of two scales, $\times 6700$.

Fig. 39. M. oviformis, replica of the outer side of an immature scale, $\times 6700$.

Fig. 40. $M$. oviformis, replica of the outer side of a mature, but rather round, scale, $\times 6700$.

Fig. 41. $M$. oviformis, direct electron micrograph of three bristle ends, $\times 6700$.

\section{Plate 6}

Fig. 42. Mallomonas adamas, replica showing a portion of the unbroken armour near the rear of a cell, $\times \mathbf{2 0 0 0}$.

Fig. 43. M. adamas, replica of outer side of a body scale, $\times 6700$.

Fig. 44. $M$. adamas, replica of the outer side of an anterior scale and the inner side of a body scale, $\times 6700$.

Fig. 45. $M$. allorgei, replica of the outer side of an immature body scale, $\times 6700$

Fig. 46. $M$. allorgei, direct electron micrograph of a body scale, $\times 6700$

Fig. 47. M. allorgei, replica of the outer side of an anterior scale. Portions of both the inner and outer sides of other scales are showing. $\times 6700$.

Fig. 48. $M$. allorgei, replica of a complete small cell with the anterior end pointing downwards, showing juvenile scales, $\times 2000$.

Fig. 49. M. allorgei, replica of the inner side of two scales, $\times 6700$.

Fig. 50. M. adamas, replica of the outer side of a group of rear scales, two showing an elongated projection, $\times 6700$. 


\section{Journal of General Microbiology, Vol. 22, No. 3}

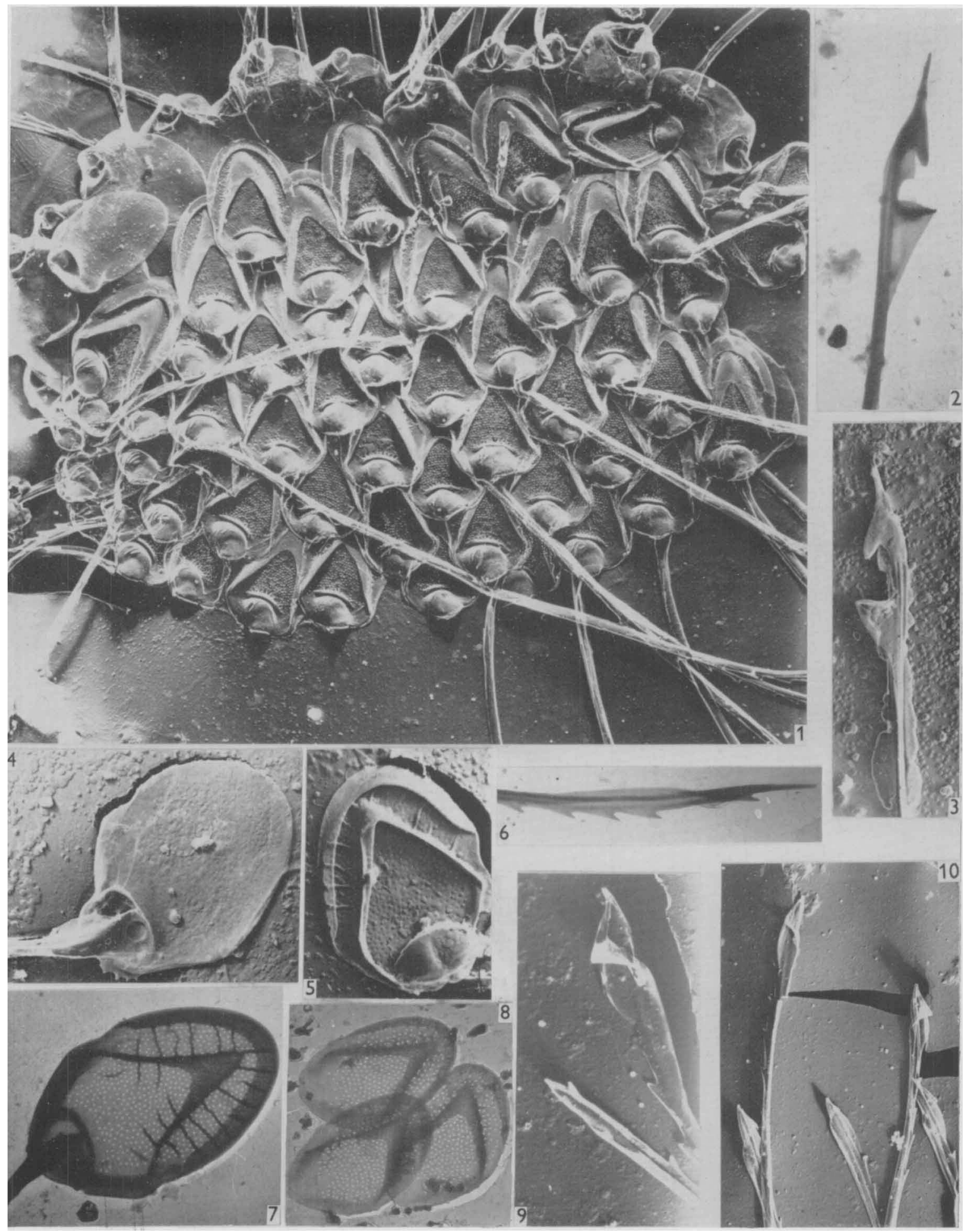

K. Harris and D. E. Bradley--A taxonomic study of mallomonas.

Plate 1 
Journal of General Microbiology, Vol. 22, No. 3

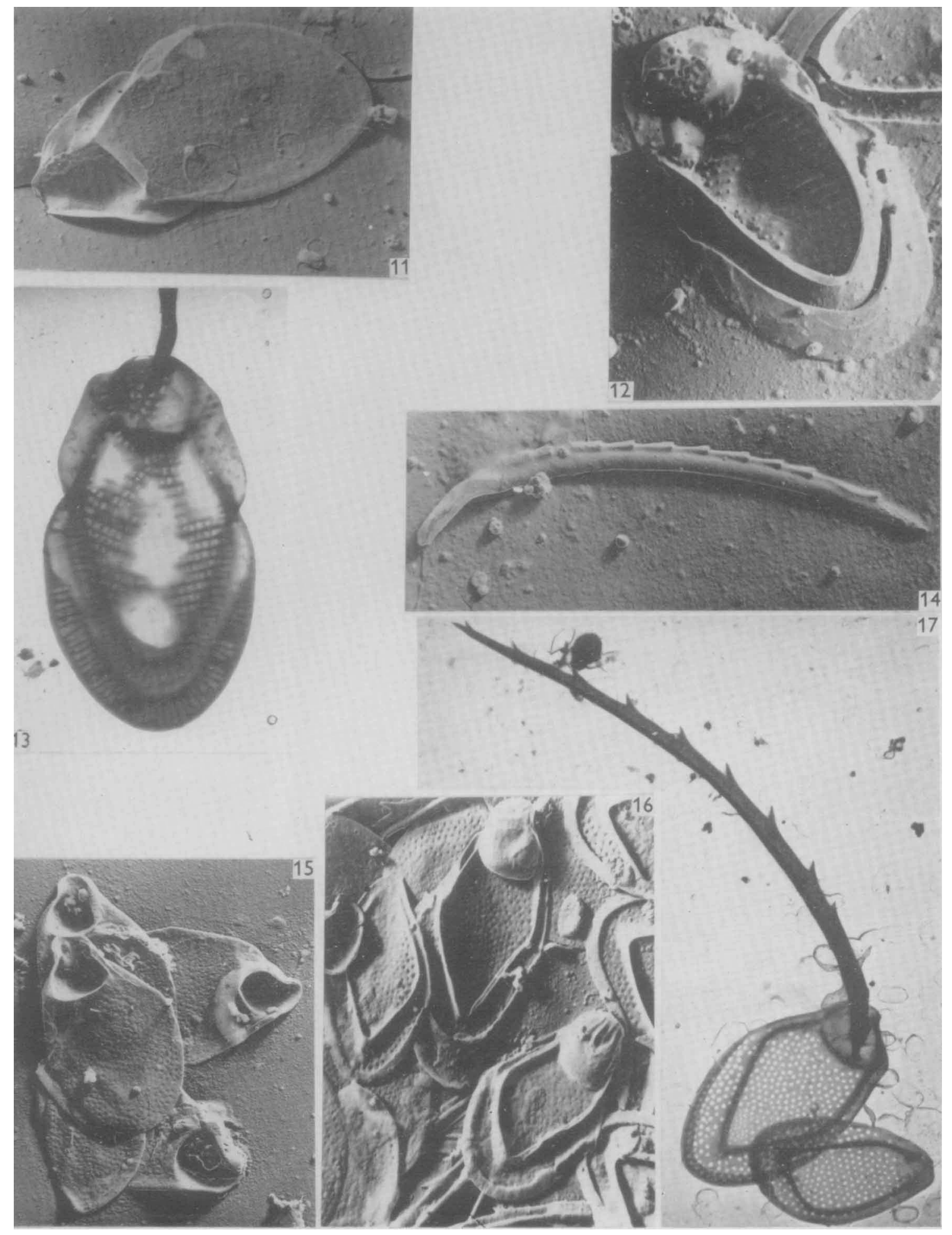

K. Harris and D. E. Bradley-A taxonomic study of mallomonas.

Plate 2 
Journal of General Microbiology, Vol. 22, No. 3
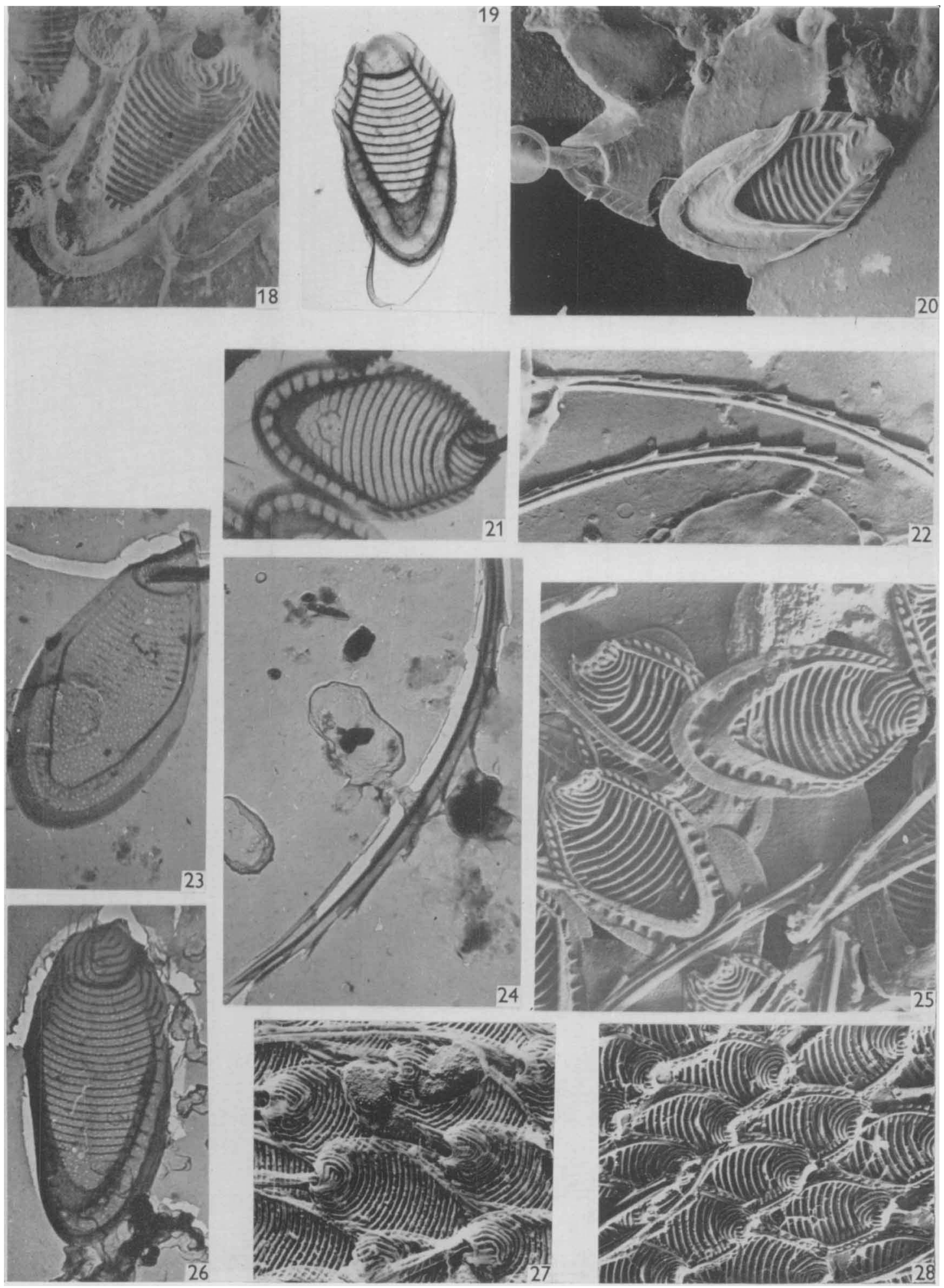

K. Harris and D. E. Braduey-A taxonomic study of Mallowonas.

Plate 3 
Journal of General Microbiology, Vol. 22, No. 3

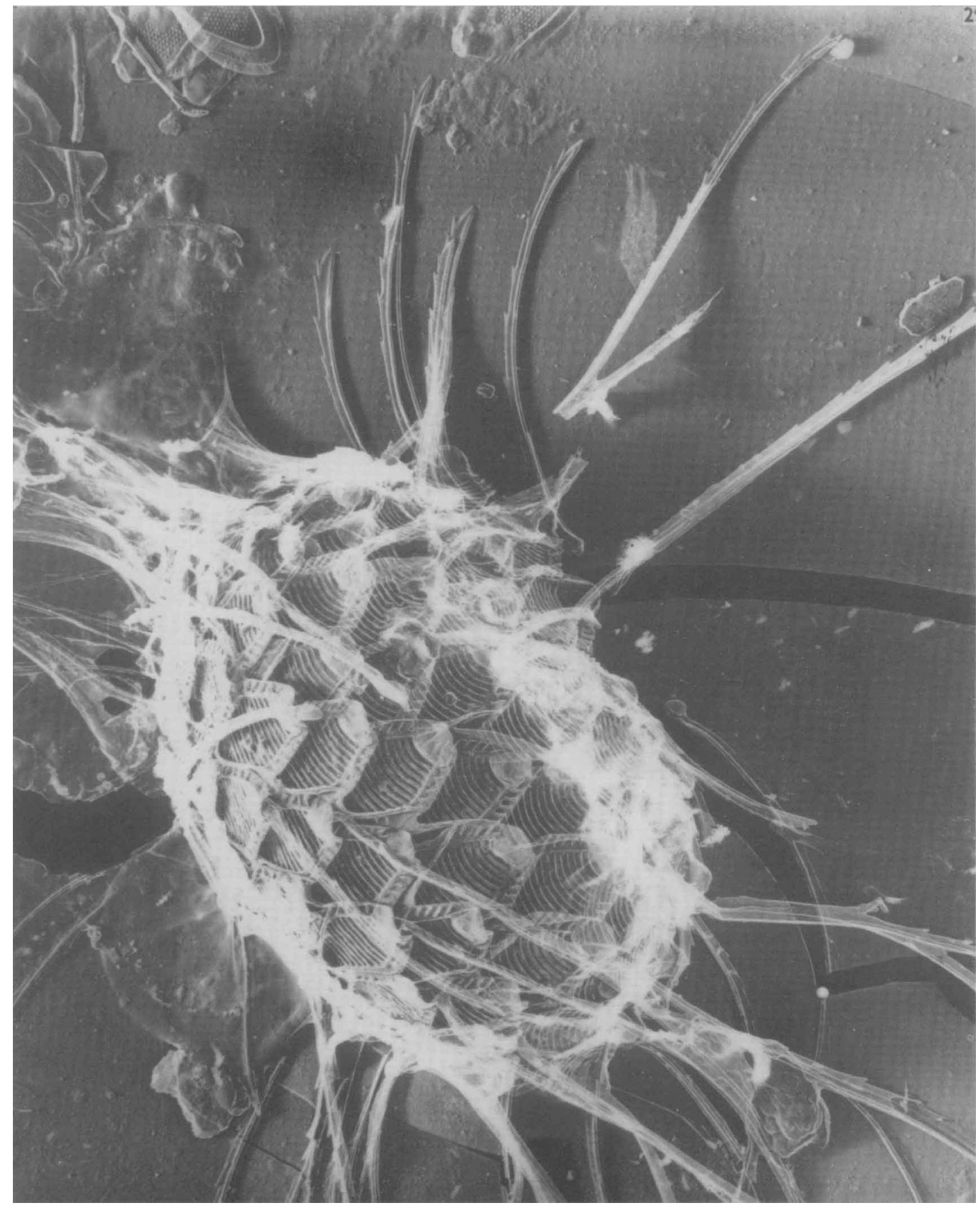

K. IIarris and D. E. Bradley-A taxonomic study of mallononas. PLATI: 4 
Journal of General Microbiology, Vol. 22, No. 3
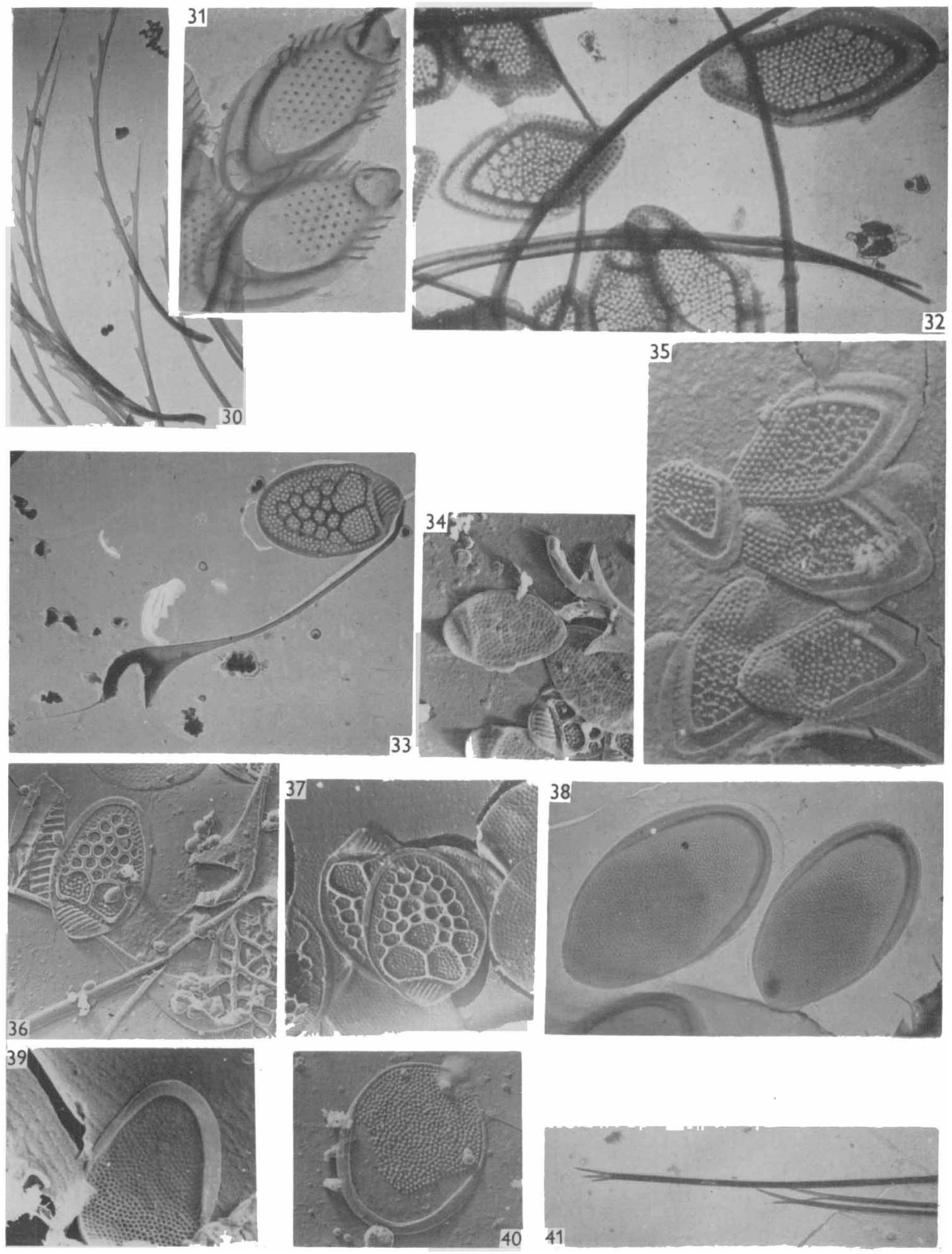

K. Harris and D. E. Bradiey-A taxonomic stedy of mallowonas.

Plate 5 
Journal of General Microbiology, Vol. 22, No. 3
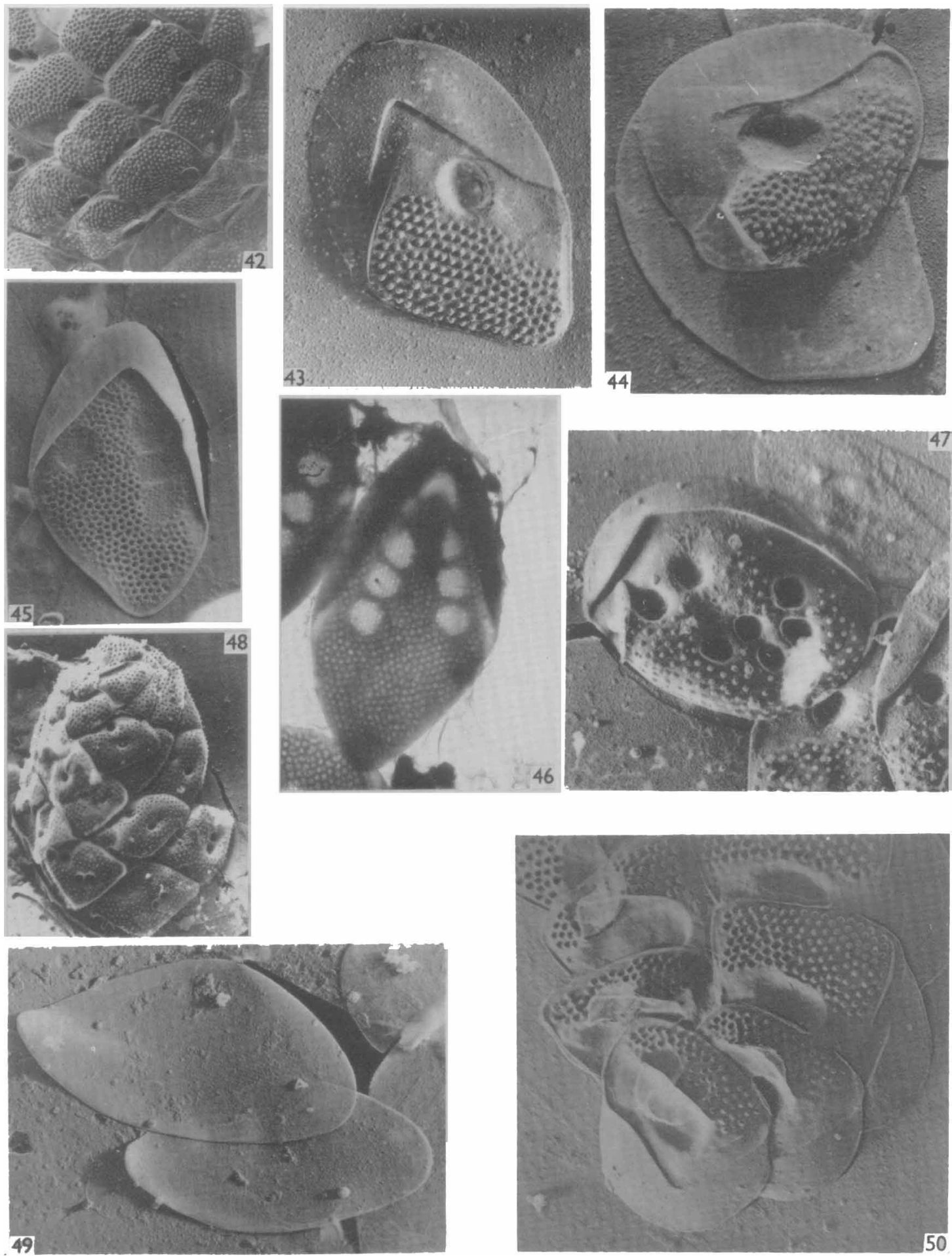

K. Harris and D. E. Braidiy-A taxonomic study of hallohonas.

Plate 6 
Journal of General Microbiology, Vol. 22, No. 3

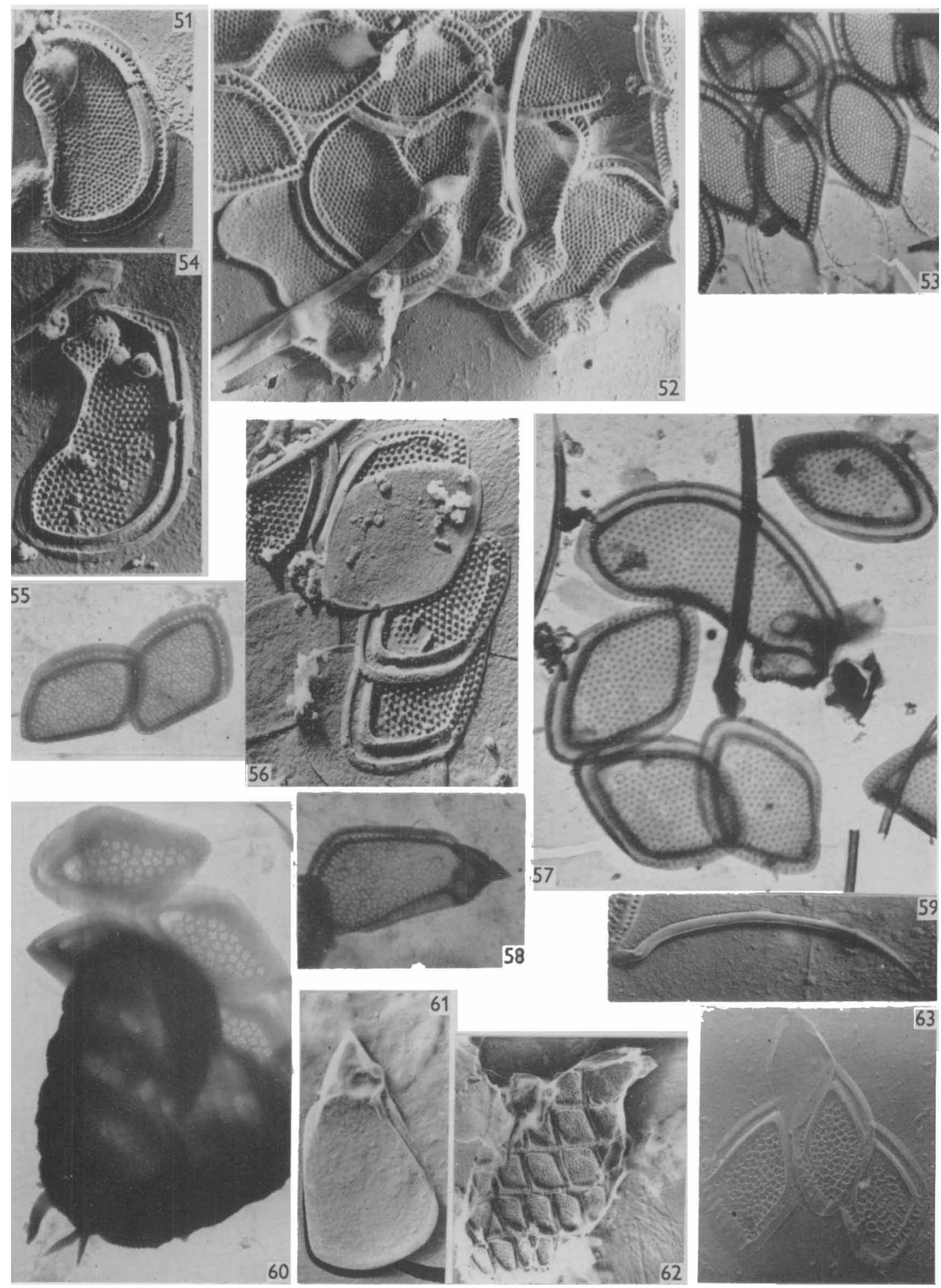

K. Harris and D. E. Bradley-A taxonomic study of mallononas.

Plate 7 


\section{Plate 7}

Fig. 51. Mallomonas phasma, replica of the outer side of an anterior scale, $\times 6700$.

Fig. 52. M. phasma, replica of the outer side of a group of anterior and body scales and the inner side of one anterior scale with the proximal part of two bristles, $\times 6700$.

Fig. 53. M. phasma, direct electron micrographs of a group of body scales. The impressions of three scales which have fallen off the film are seen at the bottom of the figure, $\times 6700$.

Fig. 54. M. mangofera, replica of the outer side of an anterior scale, $\times 6700$.

Fig. 55. M. pumilio var. silvicola, direct electron micrograph of two body scales, $\times 6700$.

Fig. 56. M. mangofera, replica of a group of body scales, some showing the inner and some the outer side, $\times 6700$.

Fig. 57. M. mangofera, direct electron micrograph of one anterior and three body scales and the proximal end of a bristle. The scale in the top right hand corner with a short spine is probably from the extreme rear. $\times 6700$.

Fig. 58. $M$. pumilio var. silvicola, direct electron micrograph of an anterior scale, $\times 6700$.

Fig. 59. M. pumilio var. silvicola, replica of anterior bristle, $\times 6700$.

Fig. 60. M. pumilio, direct electron micrograph of the rear end of a cell showing a few detached body scales and the silhouette of the rear with three spines, $\times 6700$.

Fig. 61. M. pumilio var. silvicola, replica of the inner side of an anterior scale, $\times 6700$.

Fig. 62. M. pumilio var. silvicola, replica of an unbroken cell, $\times 2000$.

Fig. 63. M. pumilio, replica of four body scales, three of these being normal and the upper immature. $\times 6700$.

(Received 18 December 1959) 